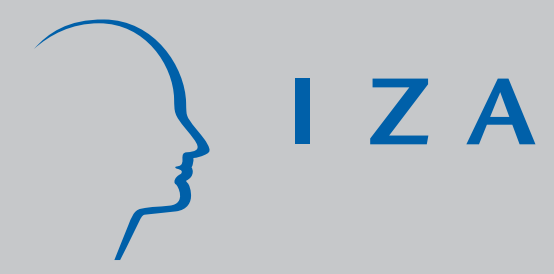

IZADP No. 3328

Learning Unethical Practices from a Co-worker: The Peer Effect of J ose Canseco

Eric D. Gould

Todd R. Kaplan

J anuary 2008 


\title{
Learning Unethical Practices from a Co-worker: The Peer Effect of Jose Canseco
}

\author{
Eric D. Gould \\ Hebrew University, Shalem Center, \\ CEPR, CREAM and IZA \\ Todd R. Kaplan \\ Haifa University \\ and University of Exeter \\ Discussion Paper No. 3328 \\ January 2008 \\ IZA \\ P.O. Box 7240 \\ 53072 Bonn \\ Germany \\ Phone: +49-228-3894-0 \\ Fax: +49-228-3894-180 \\ E-mail: iza@iza.org
}

\begin{abstract}
Any opinions expressed here are those of the author(s) and not those of IZA. Research published in this series may include views on policy, but the institute itself takes no institutional policy positions.

The Institute for the Study of Labor (IZA) in Bonn is a local and virtual international research center and a place of communication between science, politics and business. IZA is an independent nonprofit organization supported by Deutsche Post World Net. The center is associated with the University of Bonn and offers a stimulating research environment through its international network, workshops and conferences, data service, project support, research visits and doctoral program. IZA engages in (i) original and internationally competitive research in all fields of labor economics, (ii) development of policy concepts, and (iii) dissemination of research results and concepts to the interested public.
\end{abstract}

IZA Discussion Papers often represent preliminary work and are circulated to encourage discussion. Citation of such a paper should account for its provisional character. A revised version may be available directly from the author. 
IZA Discussion Paper No. 3328

January 2008

\section{ABSTRACT \\ Learning Unethical Practices from a Co-worker: The Peer Effect of Jose Canseco*}

This paper examines the issue of whether workers learn productive skills from their coworkers, even if those skills are unethical. Specifically, we estimate whether Jose Canseco, one of the best baseball players in the last few decades, affected the performance of his teammates. In his autobiography, Canseco claims that he improved the productivity of his teammates by introducing them to steroids. Using panel data on baseball players, we show that a player's performance increases significantly after they played with Jose Canseco. After checking 30 comparable players from the same era, we find that no other baseball player produced a similar effect. Clearly, Jose Canseco had an unusual influence on the productivity of his peers. These results are consistent with Canseco's controversial claims, and suggest that workers not only learn productive skills from their co-workers, but sometimes those skills may derive from unethical practices. These findings may be relevant to many workplaces where competitive pressures create incentives to adopt unethical means to boost productivity and profits.

JEL Classification: J24

Keywords: peer effects, corruption, crime, externalities

Corresponding author:

Eric D. Gould

Department of Economics

Hebrew University of Jerusalem

Mount Scopus

Jerusalem 91905

Israel

E-mail: eric.gould@huji.ac.il

\footnotetext{
*We thank Guy Stecklov for helpful comments.
} 


\section{Introduction}

There is a growing literature that stresses the importance of the environment in determining the outcomes of individuals. Most of this literature is concerned with examining how peers and environmental factors affect youth behavior regarding their educational achievements, health, criminal involvement, work status, and other economic outcomes. ${ }^{1}$ This paper examines the issue of how workers affect the productivity of other workers. If workers learn valuable skills and work habits from their co-workers, then "peer effects" between workers should exist in many work environments. A peer effect across workers could also result from behavioral considerations such as group norms, peer pressure, shame, and guilt. Recent work suggests that peer effects between workers are empirically significant. ${ }^{2}$

The existing literature, however, has not examined whether workers sometimes learn unethical practices from their co-workers in order to boost their productivity. A high payoff to performance naturally creates incentives to adopt any means necessary to boost productivity. Given that there is heterogeneity in skill, risk aversion, and moral character, these incentives will sometimes be strong enough for at least some workers to adopt unethical practices which enhance productivity. Once one worker adopts questionable methods which seem to be effective, competitive pressures may lead others to follow suit in order to get ahead, or perhaps just to stay even with other workers who are adopting similar techniques.

This mechanism is a plausible explanation for the apparent widespread use of performanceenhancing drugs in baseball, cycling, and track and field. Outside the world of sports, this diffusion process could show up through the adoption of dubious accounting methods, questionable ethics by lawyers, political corruption, noncompliance with public disclosure laws, cheating by students, biased reporting by the media, cheating in academic research, or other ways of skirting legal or ethical requirements. The literature on crime has found that criminal activity does respond to economic conditions (see Gould, Weinberg, and

\footnotetext{
${ }^{1}$ See Angrist and Lang (2004), Guryan (2004), Hoxby (2000), Sacerdote (2001), Zimmermann (2003), Katz, Kling, and Liebman (2001), Edin, Fredriksson, and Aslund (2003), Oreopoulos (2003), Jacob (2004), Weinberg, Reagan, and Yankow (2004), Gould, Lavy and Paserman (2004a and 2004b).

${ }^{2}$ See Kandel and Lazear (1992), Ichino and Maggi (2000), Winter (2004), Mas and Moretti (2006), and Gould and Winter (2007, forthcoming).
} 
Mustard, 2002). Here, we highlight the idea that in the absence of persistent monitoring and rigid enforcement of ethical and legal practices, competitive pressures may lead to a "rat race" among workers to learn unethical behavior from co-workers in order to boost their productivity. As such, this paper makes a contribution to the recent literature that has demonstrated that agents do respond to incentives to cheat or engage in corruption (Duggan and Levitt, 2002; Jacob and Levitt, 2003; Wolfers, 2006; and Kuziemko and Werker, 2006).

To examine the empirical relevance of this issue, we estimate whether Jose Canseco, one of the best baseball players in the 1980's and 1990's, affected the productivity of his fellow teammates. Among his many accomplishments, Jose Canseco was the first player in professional baseball to join the "40-40 Club" (40 home runs and 40 stolen bases in a season). Canseco was not only one of the most productive players of his era, he was highly controversial both on and off the field, and remains even more so after his retirement in 2001. During his playing career, he was frequently in the tabloids for incidents such as being arrested for bringing a loaded weapon onto a university campus, crashing his own car into his wife's car, and dating Madonna. While he was still playing, rumors circulated about his use of steroids, but he denied them and even considered suing reporters for libel. ${ }^{3}$ However, when he retired in 2001, Canseco admitted to using steroids, and claimed that the phenomenon was so widespread that "there would be no baseball left if they drug-tested everyone today" (Bryant, 2005).

In 2005, Canseco wrote a highly controversial book, "Juiced," in which he claims not only to have taken steroids throughout his playing career, but also that he gave them to his fellow teammates. The self-proclaimed "Godfather of Steroids" claimed to be a pioneer of steroid use, and takes credit for igniting a contagion of drug use in professional baseball. ${ }^{4}$ He specifically named six famous power-hitters that he claims to have personally injected with steroids, and claimed that his influence was much wider than that. He writes in his book (page 134): "My expertise on steroids could make other players around me a lot

\footnotetext{
3 "Once the rumour went out that I was on steroids - though no one presented smoking guns-I was persona-non-grata. I wanted to sue Boswell, but in the end, it just didn't seem worth my time." ("Juiced", page 117)

${ }^{4}$ Chapter 19 of "Juiced" is titled "The Godfather of Steroids."
} 
better too." Other writers have claimed that Canseco was known as the "The Chemist" (Bryant, 2005 page 189) and the "Typhoid Mary of Steroids" (Fainaru-Wada and Williams, 2006, page xiii). Indeed, taking steroids is not simple. According to Canseco, steroids are effective only if they are used correctly in conjunction with human growth hormone, lifting weights, a proper diet, and abstinence from recreational drugs. He claimed that he obtained his knowledge from extensive reading, talking to weightlifters, a friend who used them, and experimenting on himself. He writes (page 135), "I was the first to educate others about how to use them, the first to experiment and pass on what I'd learned, and the first to get contacts on where to get them. I taught which steroid has which effect on the body, and how to mix or "stack" certain steroids to get a desired effect."

Canseco claimed that he shared his knowledge not only with other players, but also with trainers who would transmit the knowledge throughout the league. He writes (page 211) that: "As soon as the trainers I talked to started getting involved, the steroid floodgates burst. The players started doing them right there in the locker room, so openly that absolutely everybody knew what was happening. It was so open, the trainers would jokingly call the steroid injections B12 shots and soon the players had picked up on that little code name, too." Two years after Canseco's book, the Mitchell Report (2007) also made accusations of widespread use of steroids and human growth hormone in professional baseball. The two main sources of information for the report came from two trainers (Kirk Radomski and Brian McNamee) who provided evidence that they supplied 53 players with steroids and human growth hormone. McNamee is directly linked to Canseco, since they both worked for the Toronto Blue Jays in 1998, and McNamee admits in the report that he consulted with Canseco on the use of steroids and considered him a knowledgeable expert. ${ }^{5}$ McNamee later went on to inject many other players during his tenure with the New York Yankees, and thus, Canseco has a direct link to the contagion outlined in the Mitchell Report.

\footnotetext{
${ }^{5}$ The Mitchell Reports (2007) states on pages 169-170: "During the 1998 season (around the time of the injections), Clemens showed McNamee a white bottle of Anadrol-50. Clemens told McNamee he was not using it but wanted to know more about it. McNamee told Clemens not to use it. McNamee said he took the bottle and gave it to Canseco." In footnote 387 on page 170, it states: "McNamee stated that he showed the bottle to Canseco because he thought that Canseco was knowledgeable and he felt comfortable approaching him. According to McNamee, Canseco volunteered to take the bottle."
} 
Interestingly, the most notorious accusation in the Mitchell Report is also linked to Canseco. In the report, McNamee claims that he supplied steroids to Roger Clemens, who is widely considered one of the greatest pitchers of all time. ${ }^{6}$ Clemens and Canseco were teammates in 1998 in Toronto, and McNamee testifies that Clemens asked McNamee for help with steroids for the first time shortly after he witnessed Clemens having a meeting with Canseco. ${ }^{7}$ Canseco admits that he never saw Clemens take steroids, but he told the Mitchell Commission that he practically encouraged Clemens to use steroids by explaining on numerous occasions "the benefits of Deca-Durabolin and Winstrol and how to 'cycle' and 'stack' steroids." 8 In his book, Canseco also talks about conversations with Clemens about the need for pitchers like him to take steroids in response to the widespread use of batters who were gaining the upper hand. ${ }^{9}$

However, considering Canseco's tarnished reputation and his penchant for doing just about anything for money, no one really knows whether his claims are true or whether they were part of a publicity stunt to help promote his book. His claims have been disputed, and even the Mitchell Report (2007) did not give much credence to his testimony, despite the fact that Canseco was one of the only current or former players who agreed to cooperate with the investigation. ${ }^{10}$ Although many suspect that at least some of his claims are true,

\footnotetext{
${ }^{6}$ In response to the Mitchell Report, Clemens denies all accusations of using steroids and human growth hormone, but admits to taking shots of B12. However, two years prior to the Mitchell Report (2007), Canseco not only claimed that the term "B12 shot" was a nickname for steroids, but he specifically mentioned that Clemens used that term as a euphemism for steroids in their conversations. Canseco writes on page 211: "I've never seen Roger Clemens do steroids, and he never told me that he did. But we've talked about what steroids could do for you, in which combinations, and I've heard him use the phrase B12 shot with respect to others."

${ }^{7}$ The Mitchell Report states on page 168: "McNamee attended a lunch party that Canseco hosted at his home in Miami. McNamee stated that, during this luncheon, he observed Clemens, Canseco, and another person he did not know meeting inside Canseco's house, although McNamee did not personally attend that meeting. . . . Toward the end of the road trip which included the Marlins series, or shortly after the Blue Jays returned home to Toronto, Clemens approached McNamee and, for the first time, brought up the subject of using steroids. Clemens said that he was not able to inject himself, and he asked for McNamee's help."

${ }^{8}$ Mitchell Report (2007), page 168.

${ }^{9}$ Canseco writes on page 211: "A lot of pitchers did steroids to keep up with hitters. If everyone else was getting stronger and faster, then you wanted to get stronger and faster, too. If you were a pitcher, and the hitters were all getting stronger, that made your job that much more difficult. Roger (Clemens) used to talk about that a lot. 'You hitters are so darn strong from steroids,' he'd say. 'Yeah, but you pitchers are taking it too. You're just taking different types,' I'd respond."

${ }^{10}$ Three of the seven players that Canseco claimed in his book that he personally injected with steroids were not even mentioned in the report (Ivan Rodriguez, Wilson Alvarez, and Dave Martinez). Three of the other players were cited by the report, but not for evidence provided by Canseco. Canseco also
} 
the same people often suspect that many are exaggerated. For example, Bryant (2005, page 373) writes of Jose Canseco and his book: He is the mysterious, frustrating character he was as a player: gifted, intelligent, and provocative, yet given to exaggeration, spite, and contradiction. In making his points, he violates the tenet of clubhouse secrecy that for years maintained the steroid era. He violates the trust of the players with whom he won and lost games, with whom he caroused, drank, and laughed. Canseco returns years of ridicule with a withering indictment of the sport.

This paper analyzes whether there is any empirical evidence to support the notion that Jose Canseco affected the performance of his teammates by turning them on to steroid use. The hypothesis is tested using panel data on the performance of baseball players from 1970 to 2003. After controlling for the individual fixed-effect of each player and a rich set of other control variables (experience, year effects, home ballpark characteristics, division effects, and managerial quality), the empirical analysis shows that a player's performance significantly increases after playing on the same team with Jose Canseco. This result is especially true for measures of performance like power hitting which are typically affected by physical strength. However, the results are significant for simple batting performance as well, where baseball folklore maintains that physical strength is not a dominant factor.

The results are smaller, but still significant, if the sample excludes the six players that Jose Canseco claims to have personally injected with steroids. This pattern is consistent with the idea that these players did indeed benefit from Canseco's human capital in chemistry, but they also might indicate that Canseco "cherry-picked" six of the most productive players that he played with, even if they are completely innocent, just for the promotional value of creating a larger scandal. Therefore, our findings that the results are significant for both the entire sample (which Canseco could not possibly "cherry pick" for his book) and the sample without the six players present strong evidence that Canseco had a "positive" influence on the productivity of his teammates. We then check to see if 30 other comparable players from the same era generated similar positive effects on their teammates. This analysis reveals no evidence of similar effects from any other player named other players that he did not personally inject as users, and these players were not mentioned in the report either (Bret Boone, Tony Saunders, and Brady Anderson). 
- thus indicating that Jose Canseco had an unusual influence on the productivity of his teammates.

It is important to note that the results are not driven by a common shock to all players on the same team, which is always a potential problem in the identification of peer effects. There are several reasons for this. First, Canseco played on ten different teams throughout his career. In fact, the seven players that Canseco claimed to have injected played on three different teams with him. ${ }^{11}$ Second, the positive effect of Canseco on his peers shows up after they no longer play with him, and therefore, are playing for various teams in the league. So, the results could not come from a common shock to all players on one team. Third, as stated above, we found no evidence of peer effects for six power-hitters who played with Canseco and shared the same coaches and team characteristics, which refutes the idea that the effect is coming from the team rather than Canseco himself.

A word of caution is appropriate regarding the interpretation of our findings. Although the results are consistent with Canseco's claims that he improved his teammates by introducing them to steroids, the results cannot identify exactly why his teammates seemed to have benefited from playing with him. It is possible that they benefitted from his workout habits, batting technique, work ethic, etc. However, in the very least, the evidence provides considerable back-up to his bravado: "I don't think there's any question that when I arrived in Texas the other Rangers saw me as a useful resource" ("Juiced," page 134). Given the multi-million dollar incentives inherent in professional baseball, we now show you why his teammates felt that way.

\section{The Data and Background}

The data was obtained from the "Baseball Archive" which is copyrighted by Sean Lahman, and is a freely available on the Internet for research purposes. The data contains extensive personal and yearly performance information on players, coaches, and teams for every season of professional baseball. The sample is restricted to the seasons between 1970 and

\footnotetext{
${ }^{11}$ McGwire played with Canseco on the Oakland A's in the late 1980's; Palmeiro, Gonzalez, and Rodriguez played with Canseco on the Texas Rangers in the early 1990's; Giambi played with Canseco on the Oakland A's in 1997; and Alvarez and Martinez played with Canseco on the Tampa Bay Devil Rays in the late 1990's.
} 
2003. Pitchers are included in the sample if they pitched at least 10 games in a season, while non-pitchers are included if they batted at least 50 times in a season. The unit of observation is the person-year, so all variables are measured at the annual level.

Table 1 presents summary statistics for the sample. The upper portion of the table presents the means and standard deviations for standard measures of performance by non-pitchers: homeruns, strikeouts (which typically are high if you are trying to hit homeruns), RBI's (runs batted in), batting average (number of hits per time at-bat), slugging percentage (which is similar to the batting average but takes into consideration the quality of the hit), intentional walks (which are typically high if you are a dangerous batter), base on balls (typically high if you are a dangerous batter), steals (typically related to speed, but Canseco claims that steroids helped him steal by making him faster), errors (in fielding), number of times at-bat, and number of games played. The sample of non-pitchers is divided into "power hitters" (first base, outfielders, catchers, and designated hitters) and "position players" (second base, third base, and short-stop). The former category emphasizes batting with power (homeruns, slugging percentage, etc.) while the second one emphasizes fielding skills at the expense of hitting prowess. This pattern is exhibited in Table 1 which shows that power hitters hit 9.55 homeruns per year versus 6.38 for position players. The slugging percentage is also considerably higher for power hitters.

Table 1 also shows the means for variables which concern the extent to which players interacted with Canseco throughout his career. The variable "ever with Canseco" is a dummy variable for ever playing on the same team with Canseco, while the variable called "currently with Canseco" is a dummy variable for currently being on the same team as Canseco in a given year. Table 1 indicates the 12 percent of the players in the sample played with Canseco at some point in their careers, while 2 percent were currently playing with him in a given year. ${ }^{12}$

The bottom panel of Table 1 presents summary statistics for pitchers. The standard indicator of a pitcher's performance is called the ERA (Earned Run Average). ${ }^{13}$ A higher

\footnotetext{
${ }^{12}$ Only 2 percent of the players played with Canseco in a given year because there are 30 teams in professional baseball (as of 2000), and Canseco played in only half of the seasons in our sample.

${ }^{13}$ This measure takes the number of runs that a pitcher allows the opposing team to obtain, and scales it by the number of innings played, so that it represents the average number of runs which would have
} 
ERA reflects poorer performance. The average ERA is 4.20, while 13 percent of the pitchers played at some point with Canseco and 2 percent play concurrently on the same team with him.

Table 2 presents summary statistics for a list of individual players. The list includes Jose Canseco, the six power-hitters named by Jose Canseco as players that he personally injected with steroids (Rafael Palmeiro, Jason Giambi, Mark McGwire, Juan Gonzalez, Ivan Rodriguez, and Dave Martinez), Ken Caminiti (who admitted that he took steroids but was not implicated by Canseco and never played with Canseco), and three leading power-position players from the 1990's that have never been implicated in any scandal and never played with Jose Canseco (Ken Griffey Jr., Ryne Sandberg, and Cecil Fielder). ${ }^{14}$ Like Canseco, most of these other players were voted "most valuable player" at some point in their career (Canseco in 1988, Sandberg in 1984, Caminiti in 1996, Gonzalez in 1996 and 1998, Griffey in 1997, Rodriguez in 1999, and Giambi in 2000).

Comparing these players to the overall average, Table 2 reveals a pattern which is very typical for excellent power hitters: many homeruns, very high slugging percentage, a little better than average batting average, many RBI's, and many strikeouts (since going for homeruns often results in strikes). Also, these players have higher than normal intentional walks and "base on balls" since the opposing teams often "pitch around" dangerous hitters to prevent them from getting a homerun.

Overall, Table 2 demonstrates that this list of players includes some of the best power hitters of their generation, although Dave Martinez is perhaps not quite at the same level as the others. The statistics for Jose Canseco certainly show that he belongs in this elite group, but he does not stand out among the group as being the absolute best. In the next section, we examine whether Jose Canseco affected the performance of his peers, and then we compare the results for Canseco to those obtained by estimating the peer effect been scored off the pitcher in a full game. The ERA is calculated by: (number of earned runs/innings pitched)*9. Runs due to defensive errors by other players are not counted, hence the name "earned" run average.

${ }^{14}$ In Canseco's book, he also named pitcher Wilson Alvarez, who is not included in the table because he is not a hitter. Ken Caminiti was the most valuable player in the National League 1996, but later admitted that he took steroids throughout his career. He ended his 15 year career in 2001 and died in 2004 of a heart attack. In an interview with Sports Illustrated in 2002, Caminiti estimated that half of the players in baseball are on steroids. (See http://espn.go.com/classic/obit/s/2004/1010/1899091.html) 
of players who had similar careers and played during the same era (the 10 players listed in Table 2 plus 20 other players who are among the best homerun hitters of all-time).

\section{The Empirical Analysis}

This section examines how the performance of individual players is affected by coming into contact with Jose Canseco. Figure 1 presents a naive analysis by showing the mean homeruns for three mutually exclusive categories of power hitting players: those that never played with Canseco, those that were playing concurrently with Canseco, and those that played with Canseco in the past. Figure 1 shows that players who played with Canseco in the past have much higher homeruns than those who played with him concurrently, and both of these groups have much higher homerun production than those that never played with him. Figure 2 displays a similar pattern regarding the slugging percentage - those that played with him are much better sluggers than those that did not.

This stark pattern could be due to the higher ability levels of players who happened to play with Canseco in the present and past, or it may be due to the causal effect of Canseco on his peers. To control for the non-random allocation of players who might have played with Canseco over time, all regressions will include individual fixed-effects. Furthermore, Figures 1 and 2 suggest that the effect of Canseco on his peers may be different between current and former teammates. Therefore, to allow for the possibility that it may take a period of time for Canseco to affect the performance of his teammates, the analysis examines whether there is evidence for an immediate effect of Canseco on the output of current teammates and whether there is a lingering effect of Canseco on former teammates. The basic regression equation is the following:

$$
\begin{aligned}
\text { performance }_{i t}= & \beta_{0}+\beta_{1}(\text { playing with canseco })_{i t}+\beta_{2}\left(\text { after canseco }_{i t}\right. \\
& +\mu_{i}+\beta_{3}(\text { other controls })_{i t}+\varepsilon_{i t}
\end{aligned}
$$

where the performance of player $i$ in year $t$ is a function of a dummy variable for whether he plays on the same team as Jose Canseco in year $t$ (playing with canseco), a dummy variable for having played with Canseco in the past but not during year $t$ (after canseco), the fixed ability of player $i$ represented by $\mu_{i}$, other observable control variables, and the 
unobserved component which varies over time, $\varepsilon_{i t}{ }^{15}$ Separate regressions are run for each performance measure listed in Table 1 . The other control variables include: the batting average in player $i$ 's division (excluding his own team) in year $t$ which controls for the quality of the pitching and batting in the team's division in the same year, the team manager's lifetime winning percentage which is an indicator for the quality of the team's coaching, the ballpark hitting factor which control for whether the team's ballpark is easy or difficult for batters in year $t$, the player's years of experience (number seasons played in the league), year effects, and dummy variables for each division. It is worth noting that these control variables have no effect on our results for the other coefficients. The unobserved ability of player $i, \mu_{i}$, is controlled for by including fixed-effects for each player $i$.

The main parameters of interest are $\beta_{1}$ and $\beta_{2}$, which indicate whether Jose Canseco affected the performance of his current or former teammates respectively. We model the potential effect of Canseco on his peers as an intercept effect, since the main factor is likely to be whether the person takes steroids or not, rather than learning how to inject steroids over time. Also, the distinction between playing "with Canseco" and playing "after Canseco" is important since even if a player did learn about steroids from Canseco, we do not know when he learned about it during his time with Canseco, but we can be sure that he already acquired the knowledge after playing with Canseco. The inclusion of a fixed-effect for each player means that we are exploiting variation in performance levels within the career of each player, rather than exploiting variation in the types of players that may have played with Canseco over time. In this manner, the empirical strategy controls for the endogenous personnel decisions of team managers. Therefore, identification of the parameters of interest comes from seeing whether variation within a given player's performance over time deviates from the typical player's experience profile in a way that is correlated with being a current or former teammate of Jose Canseco.

The basic fixed-effect regressions for power hitters are presented in Table 3. Each

\footnotetext{
${ }^{15}$ If a player played with Canseco in non-consecutive years, the variable for "playing with Canseco" is equal to 1 for every year starting in the first year that the player played with Canseco until the last year that he played with Canseco. The variable "after Canseco" is equal to one for every year after the last year that the player played with Canseco.
} 
column represents a separate regression using the indicated performance measure as the dependent variable. Column (1) shows that after controlling for all the other variables, a given power player has more homeruns on average during years that he plays with Canseco (the estimate for $\beta_{1}$ is 1.13 with standard error 0.66 ). However, homerun production seems to pick up even more after playing with Canseco (the estimate for $\beta_{2}$ is 2.91 with standard error 0.64). The same pattern exists for all of the performance measures: strikeouts, RBI's, slugging percentage, batting average, intentional walks, and "base-on-balls." Each of these performance measures increase in a statistically significant way after playing with Jose Canseco, but rarely are they statistically significant while playing with Canseco. It is worth noting that an increase in each of these measures is indicative of a higher performing "power hitter": more homeruns, more strikeouts, a higher slugging percentage, and more attempts by the other team to "pitch around" a dangerous hitter (expressed by more intentional walks and base-on-balls).

The reason why playing with Canseco has a much smaller effect than playing "after Canseco" may be due to the idea, mentioned above, that players who learn about steroids from Canseco do not take steroids during the whole time they are playing "with Canseco," but do use them during the entire time that they are former teammates with him. Alternatively, it may take some time for Canseco's positive effect to be realized, or this pattern may be due to the fact that players who play with him spend more of their time as former teammates of Canseco than being current teammates of him. For example, power hitters who played at least one season with Canseco in our sample spent 17 percent of their seasons on a team with Canseco and 33 percent of their seasons being former teammates with him. Also, the smaller effect of playing with Canseco may be due to the idea that Canseco took away scarce team resources such as playing time, attention from coaches and trainers, etc. If this were true, then similar peer effects should be found for other baseball stars. As we show later, we do not find similar effects for other stars, which casts doubt on the hypothesis that star players "crowd out" the performance of other players. If, however, we do not differentiate between current and former players by using one variable which indicates whether the player either plays currently or in the past with Canseco, the coefficient for homeruns is 2.05, and is still highly significant with a standard error of 0.549 . 
The coefficients in Table 3 are significant statistically and also sizeable in magnitude. The estimated effect of playing "after Canseco" on homeruns is 2.91 , which is $30.5 \%$ of the mean homerun production of power hitters (9.55) displayed in Table 1. After playing with Jose Canseco, a typical power hitter is also estimated to increase his RBI's by 22 percent (a coefficient of 9.174 compared to the mean RBI's of 41.78). Apparently, the benefits of playing with Canseco were quite large.

Table 4 presents additional results for power hitters using alternative measures of performance. The first three columns show that Canseco had no discernible effect on steals, fielding percentage, and fielding errors. Neither of these outcomes is considered particularly important for power hitting, nor are they typically thought of as being affected by physical strength. So, the lack of any effect for these outcomes strengthens the interpretation of the results in Table 3 that Canseco had a significantly positive effect on the hitting power of his former teammates by affecting their physical strength.

Columns (4) and (5) in Table 4 show that power hitters significantly increase their playing time (number of times at-bat and number of games played in a season) after playing with Canseco. ${ }^{16}$ Contrary to the outcomes in the first three columns, playing time should increase for a power hitter if his hitting prowess has improved. ${ }^{17}$ The effect of Canseco on playing time could be a reason why we see several power hitting performance measures increase in Table 3 after playing with Canseco. For example, a power hitter will naturally tend to hit more homeruns and RBI's if they have more chances at bat. The final column of Table 4 re-runs the regression for homeruns but controls for number of at-bats. In comparison to the results in Table 3 which did not control for the number of at-bats, the results are much smaller but still statistically significant. That is, a players homerun production increases after playing with Canseco even if we condition on the number of chances at bat. Also, it should be noted that two of the outcomes in Table 3 (slugging

\footnotetext{
${ }^{16}$ Since playing time is clearly an endogenous outcome which seems to be affected by Canseco, our preferred specification does not include playing time as a control variable. However, as discussed later, the strong positive effect of Canseco on his peers operates not only through increased playing time, but also on measures of performance that are normalized by playing time (slugging percentage and batting average).

${ }^{17}$ Also, Canseco claimed that steroids help players recover from injuries faster, which could also increase playing time. In his personal case, he claimed that steroids extended his career by enabling him to play with serious back problems.
} 
percentage and batting average) are already normalized by the number of at-bats, so the significant results for these measures indicate that the positive effect of Canseco on his teammates is not operating just through an increase in playing time.

We now turn our attention to see if Canseco had an effect on other types of players (not power hitters). The upper panel of Table 5 runs similar regressions for a sample of skilled position players (not pitchers or power hitters) and pitchers. The results indicate that skilled position players did not increase their homerun production after playing with Canseco, but they did significantly increase their batting average and slugging percentage. Canseco had no discernible effect on fielding percentage and steals. These results suggest that Canseco had no effect on measures which clearly should not be affected by steroids (fielding percentage and perhaps steals), but did have an effect on measures that are important for these types of players (batting average and slugging percentage). If Canseco did affect the physical strength of his former teammates, it is more likely to show up in the slugging percentage for these types of players than the number of homeruns, since they typically hit disproportionately more doubles and triples (which affect the slugging percentage) than homeruns. The last column of Table 5 indicates that Canseco had no effect on the performance of pitchers, measured by the pitcher's ERA. The lack of significant results for pitchers is again consistent with the idea that Canseco only had an effect by influencing the physical strength of his teammates - which is unlikely to affect a pitcher's performance since pitching has very little to do with physical strength.

Given that Canseco named six specific batters which he claimed to have personally injected with steroids, it is natural to ask whether the results so far are coming from these specific players. Table 6 compares the results for power hitters using the full sample (Table 3) to the results obtained from a sample which deletes the six named players (Rafael Palmeiro, Jason Giambi, Mark McGwire, Juan Gonzalez, Ivan Rodriguez and Dave Martinez). Across all performance measures which are indicative of power hitting performance, the results are much weaker (roughly half the size) after we delete these players from the sample, but they are still statistically significant. This pattern indicates that these six players are responsible for a sizable portion of the results, but there is still a significant effect of playing with Canseco even for other players - something we already saw in Table 
5 which showed a significant Canseco effect for non-power hitters.

The fact that the results are much smaller when we delete these players from the sample could indicate that Canseco had the biggest effect on the players that he specifically named. However, it is also true that Canseco had a good motive to name these specific players even if they were completely innocent. For example, Canseco may have named these specific players because they are high profile athletes and accusing them would help promote his book much more than accusing an unknown player of steroid use. Also, Canseco may have tried to take credit for their success, or tarnish their success in comparison to his diminished reputation. Even if Canseco deliberately lied about his effect on other players, he had to know that his claims would be more believable and would help sell more books by choosing the most obvious high profile cases of players who clearly went on to have an outstanding career after playing with him. In other words, Canseco may have overstated his expertise in chemistry, but demonstrated an intuitive sense of basic statistics by naming the cases with the strongest correlation between individual performance and playing with him on the same team. For this reason, our preferred specification is the one which includes the whole sample, since the effect of playing with Canseco (and after Canseco) is identified from a clearly exogenous variable which Canseco had no chance of affecting during the course of writing of his book. For the same reasons, we did not check Canseco's other claims in his book about steroid use by players that did not play with him - since he could easily "cherry-pick" attention-grabbing names to accuse of steroid use. However, the fact that the results are still significant for players other than the six named in the book is consistent with his claims that his expertise was valuable beyond those six players.

\section{The Peer Effect of Similar Players}

Having established that Canseco had a positive effect on power hitters and even non-power hitters, we now examine whether other baseball stars of the same era generated similar effects on their teammates. To allow for the possibility that other players may also generate a positive effect by transmitting knowledge about steroids, we estimate the peer effect of those that were named by Jose Canseco in his book. In addition, we estimate the peer 
effect for Ken Caminiti who acknowledged that he took steroids during the height of his career. For the sake of a simple comparison, we also present results for three famous players who have never been mentioned as being involved in steroid use: Ken Griffey Jr., Ryne Sandberg, and Cecil Fielder. As shown in Table 2, all of the players are similar in the sense of having outstanding careers. Later, we will systematically choose 26 players who had similar careers as Jose Canseco, and compare the results for Canseco to those obtained for all 26 players.

Table 7 presents the results using the same regression specification used to estimate the peer effect of Jose Canseco, but using one of the ten other players instead of Jose Canseco as the independent variable. One striking pattern that emerges is that many of the coefficients are negative, in contrast to the results for Canseco which are uniformly positive on every outcome. The second striking pattern is that very few coefficients are significant, again in contrast to Canseco where every coefficient is significant. In fact, four of the ten players do not have one significant coefficient for any of the seven outcomes (Giambi, McGwire, Gonzalez, and Ryne Sandberg). Two players have one significant coefficient (Fielder and Martinez), two players have significant coefficients for two of the nine outcomes (Rodriguez and Caminiti), and two players (Palmeiro and Griffey Jr.) have three significant coefficients. However, even for these players, most of the outcomes are not significant, and in contrast to Canseco, the significant coefficients for Palmeiro, Caminiti, Martinez, and Griffey Jr. are negative in sign. Rodriguez has two positive coefficients for strikeouts and at-bats, but no positive coefficients for the main indicators of power hitting (homeruns and slugging percentage).

Overall, it is clear that the results for Jose Canseco are very unusual in comparison to players who had similar careers and even players who are suspected to use steroids (Caminiti and Giambi admitted to steroid use, and Palmeiro tested positive in 2005). Furthermore, this analysis shows that the statistically significant results for Canseco are not simply a product of a large sample size, since the same sample was used to analyze the peer effect of the other ten players.

We perform a similar analysis for non-power hitters and pitchers in the bottom panel of Table 5. In contrast to the upper panel of Table 5 which showed a positive 
effect of Canseco on the slugging percentage and batting average, only two of the ten other baseball stars (Palmeiro and Sandberg) had an effect on these measures of performance. The other players exhibit no significant effects for any measure of performance, so once again, Jose Canseco seems to be in the minority in terms of his effect on peers. In the last column of Table 5, the results show that no player, including Canseco, affected the pitching performance of their former teammates. This is the first case where Canseco seems to be similar to his other baseball stars. However, this similarity is consistent with the idea that even if Canseco did affect the physical strength of his teammates, this should have no impact on his fellow pitchers since pitching is not related to physical strength. So, if physical strength is the mechanism through which Canseco affected his peers in general, we would expect no effect for pitchers, which is what we find in Table 5 .

To check the robustness of the results, we now systematically choose a sample powerhitting players who were comparable to Jose Canseco. Canseco made his professional debut in 1985, so we restrict our sample to players that started their career between 1981 and 1989. Next, we take only those players who are either on the top 100 list of career homeruns or those that were homerun hitting champions for any given year between 1985 and 2001 (for either league). Players on the all-time list obviously had great careers, while those that were hitting champions in a given year had at least one spectacular season. Jose Canseco matches both of those criteria, as do several other players on the final list. Table 8 shows the final list of 27 players and indicates which criteria they matched to be included in the sample. The sample includes 7 players that we already examined (Canseco, Griffey Jr., Fielder, Sandberg, McGwire, Palmeiro, and Gonzalez) and 20 new players. The estimated peer effect of each one of these players is presented in Table 9, which shows the estimated effect of each player on five different performance measures for power hitters (homeruns, strikeouts, intentional walks, RBI's, and slugging percentage) and two performance measures for position players (batting average and slugging percentage).

Table 9 shows once again how strikingly different Jose Canseco is from the rest of this elite group of players. The estimated effect for Canseco is positive and significant for each of the 7 outcomes. For the other 26 players, 77 percent of the coefficients are not significant even at the 10 percent level (140 out of 182 coefficients). Also, unlike Canseco, 
most of the coefficients that are significant are negative - 26 are negative and 16 are positive. That is, only 8.8 percent of the coefficients are positive and significant at the 10 percent level. Furthermore, the coefficients that are positive and significant are scattered among many players, which means that the other outcomes for these players are either not significant or negative. In other words, there is no other player that has a systematically large and significant positive effect across the seven outcomes. The only player that has a positive effect on more than two outcomes is Chili Davis, who has two coefficients that are significant only at the 10 percent level and two others at the 5 percent level. Unlike Canseco, Davis has no effect on the other three outcomes. Also, in comparison to Canseco, the coefficients for Davis are much smaller in magnitude and none are significant at the 1 percent level ( 5 out of 7 for Canseco are significant at the 1 percent level).

Overall, Table 9 shows that Canseco is highly unusual in comparison to all the elite homerun hitters of his generation. Hardly any other player displays any effect on his peers, while Canseco has a strong positive effect on every outcome. A few players do reveal a systematic pattern, but the pattern indicates a negative effect on other players. This seems to be the case for Griffey, Bonds, Sosa, Belle, and to a lesser extent, Gaetti and Palmeiro. These players are considered among the best within the 27 players listed in Table 9, so once again, the completely opposite pattern for Canseco accentuates how truly unique he was.

It is important to note that our findings refute the idea that a common shock to all players in the same environment is responsible for the estimated peer effect of Jose Canseco. In general, the identification of a peer effect is difficult to disentangle from common shocks or unobserved characteristics shared by a group of people. However, there are several indications that this is not driving our results. First, Canseco played on ten different teams throughout his career, and the evidence is consistent with his claims to have injected steroids into the six named players during his tenure with at least three teams. Second, the positive effect of Canseco on his peers shows up after they no longer play with him, and therefore, play for various teams across the league. A common, sustained shock across various teams which affects only former teammates of Jose Canseco is highly unlikely. Third, although team managers may have surrounded Canseco with 
certain types of players, it remains a mystery why a team would do this only for Canseco and not the other 30 comparable power-hitters that we checked, and it is not likely that a manager would have the incentive or foresight to build a team around players that would significantly improve their performance after they no longer play with Jose Canseco. In addition, the analysis includes a fixed-effect for each player, which means that changes in the composition of players should not drive any of our results, since we are exploiting variation over time "within" the career of each player rather than variation across players. Finally, we found no evidence of similar peer effects for six power-hitters who played with Canseco and shared the same coaches and team characteristics. Taken as a whole, these findings present strong evidence that the effect is coming from Canseco and not the shared characteristics of the team or the endogenous decisions of team managers.

\section{Conclusion}

Our analysis demonstrates that Jose Canseco had a significant effect on his former teammates. Specifically, we find that Canseco had a positive impact on outcomes such as slugging percentage, homeruns, strikeouts, intentional walks, base-on-balls, playing time, and other performance measures. The pattern of results are all indicative of increased power hitting performance. In contrast, we find no effect of Canseco on his teammates' pitching output. In this manner, the results are consistent with Jose Canseco's claims that he helped his teammates increase their physical strength by introducing them to steroids, since physical strength is considered an important factor in hitting power but not particularly useful for pitching.

We have no direct evidence, however, that Jose Canseco's teammates learned about steroids directly or indirectly from him. We do know that the evidence strongly supports his claims that he improved the physical strength of his teammates, but we have no proof that the mechanism responsible for this effect was steroids. It is possible that his teammates learned about strength conditioning or other work habits. However, this paper provides the first systematic study which shows that the evidence is consistent with Canseco's scandalous accusations. In particular, our findings support his claims that he 
started a contagion of steroid use in the late 1980's by teaching his peers and trainers about the benefits and technology of performance enhancing drugs. The recent Mitchell Report (2007) provides additional controversial evidence on the widespread use of steroids in baseball, but almost all of the evidence concerned current players or drug use in the last five to ten years. The Mitchell Report (2007) is silent on how the epidemic was ignited in the late 1980's and early 1990's, and does not offer any indication of whether steroids are effective or not. In fact, the report cites evidence (page 9) which indicates that the use of human growth hormone is not effective at all. Our findings are consistent with Canseco's claims that steroids and human growth hormone are highly effective, and that he was at the forefront of transmitting the technology of how to use them throughout professional baseball in the late 1980's and early 1990's.

Even though we do not provide direct evidence of steroid use, the evidence is not consistent with other explanations. This is best illustrated by our findings that no other player seems to have affected his teammates in the way that Jose Canseco did. After checking to see whether 30 other power-hitting stars affected their teammates, we find that none of them exhibited anything close to what we see with Jose Canseco. Across all outcomes that are indicative of being a good power hitter, Jose Canseco had a strong and significant impact on each one. For the 30 other players, hardly any of the effects were significant, and most of the coefficients that were significant were in the opposite direction (decreasing the performance of their peers). Clearly, Jose Canseco had a very unusual effect in comparison to players who had similar careers and even players who are suspected of using steroids. That is, Canseco is not just generally different from everyone else, but he appears to be unique even among known steroid users (Caminiti, Giambi, and Palmeiro). Therefore, if the source of the effect that Canseco apparently had on his teammates' batting power was due to something other than steroids (work ethic, batting techniques, weight training regimen, etc.), why do we not see similar positive effects from other elite players on their peers as well? Why would this mechanism be limited to playing with Jose Canseco?

In his book, Canseco named six specific teammates as players that he personally injected with steroids. When these names are deleted from the sample, the effect of 
Canseco on his other teammates was diminished by roughly 50 percent for all outcomes, but the coefficients were still significant. This finding supports Canseco's claims that his influence was much wider than the six people that he mentioned.

All of this evidence points to the powerful effect one worker can have on many other co-workers. This particular case demonstrates how a "peer effect" could be generated by one worker increasing the productivity of other workers, rather than working through behavioral channels such as peer pressure, shame, guilt, etc. Furthermore, this is a case where the mechanism may involve unethical means. As the literature on crime suggests, unethical behavior by one person can cause others to follow suit. ${ }^{18}$ In the context of the workplace, once one worker starts doing it, he may obtain a competitive advantage which can only be neutralized by other workers doing the same.

Ken Caminiti estimated that half the players in baseball use steroids (Verducci, 2002). Perhaps prone to exaggeration, Canseco claimed that 85 percent of major league baseball players did steroids. In his autobiography, baseball pitcher David Wells (2003) writes that "as of right now, I'd estimate 25 to 40 percent of all major leaguers are juiced. But that number's fast rising." He goes on to explain why: "Down in the minors, where virtually every flat-broke, baloney-sandwich-eating Double-A prospect is chasing after the same, elusive, multimillion-dollar payday, the use of anabolic homer-helpers is flat-out booming . . . At just about 12 bucks per shot, those steroid vials must be seen as a really solid investment."

Canseco seems to implicitly agree with Wells - he never apologizes about using steroids or about giving them to others. To him, steroids are simply a way to boost your competitive advantage. A similar attitude could explain the widespread use of performanceenhancing drugs in other sports like cycling and track and field. Outside the world of sports, similar forces may be at work in terms of accounting practices, unprofessional behavior by lawyers, political corruption, public disclosures, cheating by students, accuracy in journalism, reporting in academic research, etc. In general, the knowledge that other workers or firms are cheating could trigger others to do the same. In some cases, they will need to learn the unethical skill from a co-worker, but in some cases they may be able to

\footnotetext{
${ }^{18}$ See Glaeser et. al. (1996)
} 
figure it out on their own or search for other sources. Overall, this paper highlights the idea that in the absence of a rigid and persistent enforcement mechanism over unethical behavior, market forces could lead to a "rat race" where workers are willing to do just about anything to remain competitive. 


\section{References}

[1] Associated Press, March 27, 2003, ESPN Website: http://espn.go.com/mlb/news/2003/0227/1515302.html

[2] Angrist, Joshua D., and Kevin Lang. "Does School Integration Generate Peer effects? Evidence from Boston's Metco Program," American Economic Review, 94(5), December 2004, 1613-1634.

[3] Canseco, Jose. "Juiced: Wild Times, Rampant 'Roids, Smash Hits, and How Baseball Got Big," William Morrow, February 2005.

[4] Duggan, Mark, and Steven D. Levitt. "Winning Isn't Everything: Corruption in Sumo Wrestling," American Economic Review, 92(5), 2002, 1594-1605.

[5] Edin, Per-Anders, Peter Fredriksson, and Olof Åslund, "Ethnic Enclaves and the Economic Success of Immigrants - Evidence from a Natural Experiment," Quarterly Journal of Economics, CXVIII (2003), 329-357.

[6] Falk, Armin, and Andrea Ichino, "Clean Evidence on Peer Effects," Working Paper, European University Institute, 2003.

[7] Fainaru-Wada, Mark, and Lance Williams. "Giambi Admitted Taking Steroids," San Francisco Chronicle, December 2, 2004.

[8] Glaeser, Edward L., Bruce Sacerdote, and Jose A. Scheinkman, "Crime and Social Interactions," Quarterly Journal of Economics, 111 (2), (1996), 507-548.

[9] Gould, Eric D., and Eyal Winter. "Interactions Between Workers and the Technology of Production: Evidence from Professional Baseball," Review of Economics and Statistics, 2007, forthcoming.

[10] Gould, Eric D., Victor Lavy, and M. Daniele Paserman. "Immigrating to Opportunity: Estimating the Effects of School Quality Using a Natural Experiment on Ethiopians in Israel." Quarterly Journal of Economics, May 2004, 119 (2), 489-526.

[11] Gould, Eric D., Victor Lavy, and M. Daniele Paserman. "Does Immigration Affect the Long-Term Educational Outcomes of Natives? Quasi-Experimental Evidence," Working Paper, 2004.

[12] Gould, Eric D., Weinberg, Bruce A., and David Mustard. "Crime and Local Labor Market Opportunities in the United States: 1979-1997," Review of Economics and Statistics, 84 (1), February 2002, 45-61.

[13] Guryan, Jonathan, "Desegregation and Black Dropout Rates," American Economic Review, 94(4), September 2004, 919-943.

[14] Hanushek, Eric, John F. Kain, and Steven G. Rivkin. "New Evidence About Brown V. Board of Education: The Complex Effects of School Racial Composition on Achievement," NBER Working Paper No. 8741, 2002.

[15] Hoxby, Caroline M. "Peer Effects in the Classroom: Learning from Gender and Race Variation," NBER Working Paper No. 7867, August 2000. 
[16] Ichino, Andrea, and Giovanni Maggi. "Work Environment and Individual Background: Explaining Regional Shirking Differententials in a Large Italian Firm," Quarterly Journal of Economics, CXV(3), August 2000, 1057-1090.

[17] Jacob, Brian A. "Public Housing, Housing Vouchers and Student Achievement: Evidence from Public Housing Demolitions in Chicago," American Economic Review 94(1), March 2004, 233-258.

[18] Jacob, Brian A., and Steven D. Levitt. "Rotten Apples: An Investigation of the Prevalence and Predictors of Teacher Cheating," Quarterly Journal of Economics, 118 (3), 843-877.

[19] Kandel, Eugene, and E. P. Lazear. "Peer Pressure and Partnerships," Journal of Political Economy, 100 (4), 1992, 801-817.

[20] Katz, Lawrence F., Jeffrey R. Kling, and Jeffrey B. Liebman. "Moving to Opportunity in Boston: Early Results from a Randomized Mobility Experiment," Quarterly Journal of Economics CXVI (2001), 607-654.

[21] Kuziemko, Ilyana, and Eric Werker. "How Much Is a Seat on the SecurityCouncil Worth? Foreign Aid and Bribery at the United Nations," Journal of Political Economy, 2006, 114 (5), 905-930.

[22] Mas, Alexandre, and Enrico Moretti. "Peers at Work," NBER Working Paper 12508, September 2006.

[23] Mitchell, George J. "Report to the Commisioner of Baseball of an Independent Investigation into the Illegal Use of Steroids and Other Performance Enhancing Substances by Players in Major League Baseball," http://files.mlb.com/mitchrpt.pdf, December 2007.

[24] Oreopoulos, Philip. "The Long-Run Consequences of Living in a Poor Neighborhood," Quarterly Journal of Economics, CXVIII (4), (2003), 1533-1575.

[25] Sacerdote, Bruce. "Peer Effects with Random Assignment: Results for Dartmouth Roommates," Quarterly Journal of Economics, CXVI (2001), 681-704.

[26] Verducci, Tom. "Steroids in Baseball: Confessions of an MVP," Sports Illustrated, June 3, 2002.

[27] Weinberg, Bruce A., Patricia B. Reagan, and Jeffrey J. Yankow. "Do Neighborhoods Affect Hours Worked: Evidence from Longitudinal Data," Journal of Labor Economics, 2004, 22 (4), 891-924.

[28] Wells, David, and Chris Kreski. "Perfect I'm Not! Boomer on Beer, Brawls, Backaches and Baseball," William Morrow, 2003.

[29] Winter, Eyal. "Incentives and Discrimination," American Economic Review, 94 (3), (2004), 764-773.

[30] Wolfers, Justin. "Point Shaving: Corruption in NCAA Basketball," American Economic Review 96(2), May 2006, 279-283.

[31] Zimmerman, David J. "Peer Effects in Academic Outcomes: Evidence from a Natural Experiment," Review of Economics and Statistics, LXXXV (2003), 9-23. 


\section{Figure 1}

Homeruns for Power Hitters from 1995 to 2000

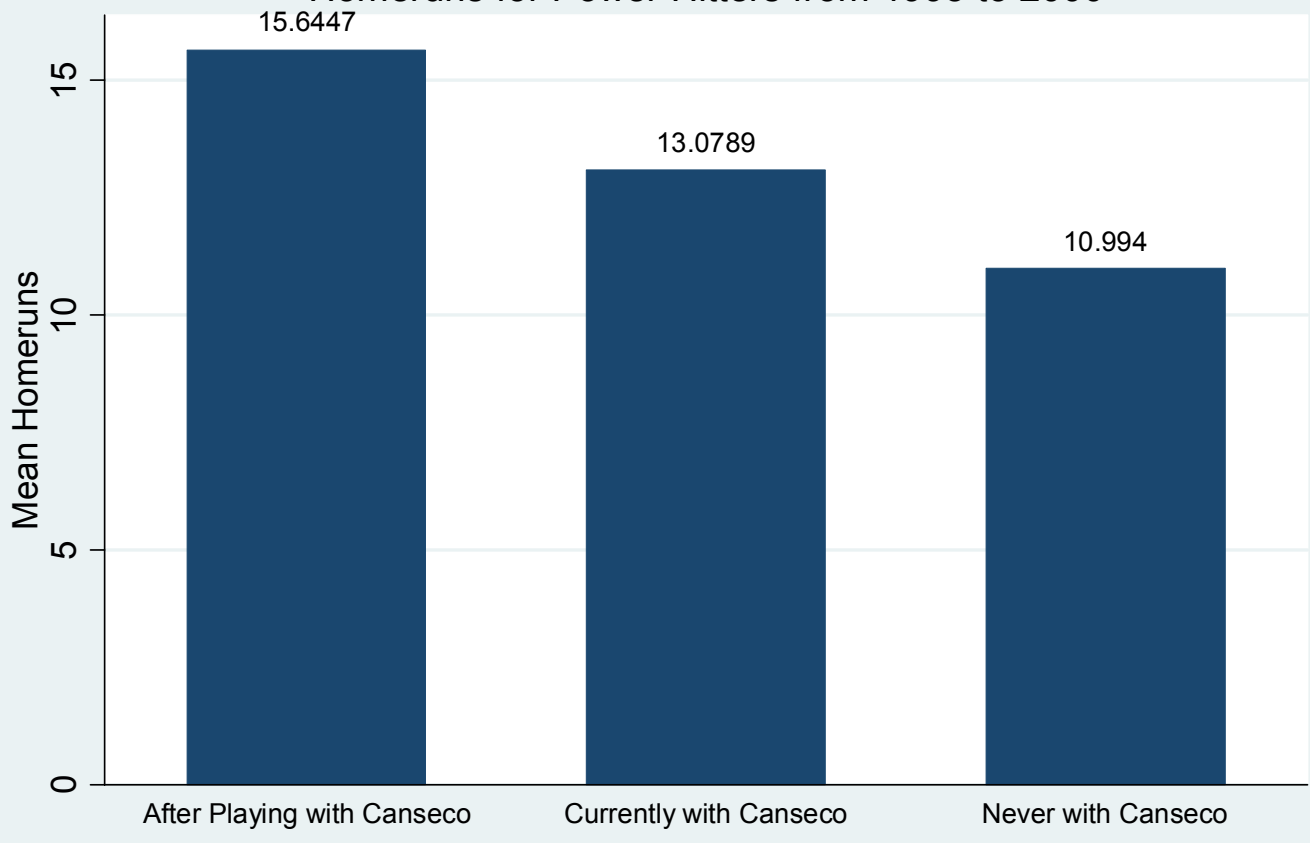

Figure 2

Slugging Percantage for Power Hitters from 1995 to 2000

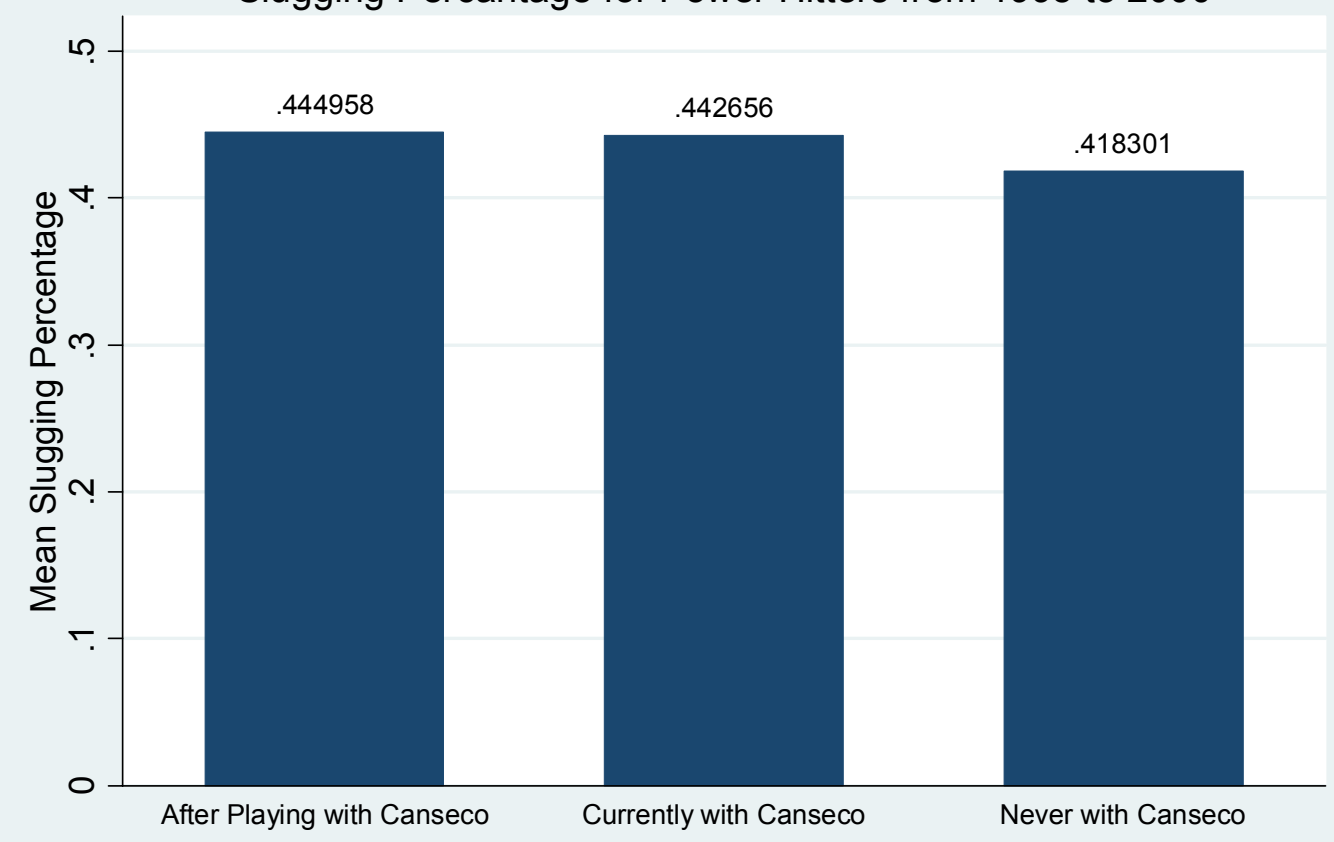




\begin{tabular}{|c|c|c|c|c|}
\hline & \multicolumn{2}{|c|}{ Power Hitters } & \multicolumn{2}{|c|}{ Position Players } \\
\hline & Mean & $\begin{array}{l}\text { Standard } \\
\text { Deviation }\end{array}$ & Mean & $\begin{array}{c}\text { Standard } \\
\text { Deviation }\end{array}$ \\
\hline Homeruns & 9.55 & $(9.72)$ & 6.38 & $(7.81)$ \\
\hline Strikeouts & 51.76 & (33.34) & 47.85 & (30.19) \\
\hline RBI & 41.78 & $(30.97)$ & 36.25 & $(26.43)$ \\
\hline Slugging Percent & 0.397 & $(0.086)$ & 0.359 & $(0.078)$ \\
\hline Batting Average (BA) & 0.258 & $(0.040)$ & 0.252 & $(0.038)$ \\
\hline Intentional Walks & 3.31 & $(4.23)$ & 2.41 & $(3.30)$ \\
\hline Base On Balls & 32.40 & $(24.85)$ & 30.61 & $(22.85)$ \\
\hline Steals & 6.46 & $(10.89)$ & 7.14 & $(10.15)$ \\
\hline Fielding Percent & 0.98 & $(0.02)$ & 0.97 & $(0.02)$ \\
\hline Errors & 4.30 & $(3.65)$ & 11.54 & $(7.40)$ \\
\hline At-Bats & 310.41 & $(175.36)$ & 332.96 & (181.60) \\
\hline Games & 99.02 & $(40.57)$ & 103.21 & $(41.46)$ \\
\hline Ever with Canseco & 0.12 & $(0.32)$ & 0.12 & $(0.33)$ \\
\hline Currently with Canseco & 0.02 & $(0.14)$ & 0.02 & $(0.14)$ \\
\hline Division Batting Ave. & 0.266 & $(0.007)$ & 0.266 & $(0.007)$ \\
\hline Manager Winning Pct. & 0.50 & $(0.04)$ & 0.50 & $(0.04)$ \\
\hline Ballpark Hitting Factor & 100.22 & $(4.92)$ & 100.21 & $(5.03)$ \\
\hline \multirow[t]{3}{*}{ Observations } & \multicolumn{2}{|c|}{9534} & \multicolumn{2}{|c|}{4826} \\
\hline & & \multicolumn{2}{|c|}{ Pitchers } & \\
\hline & & Mean & $\begin{array}{c}\text { Standard } \\
\text { Deviation }\end{array}$ & \\
\hline Earned Run Average & & 4.20 & $(1.44)$ & \\
\hline Ever with Canseco & & 0.13 & $(0.33)$ & \\
\hline Currently with Canseco & & 0.02 & $(0.15)$ & \\
\hline Observations & & & & \\
\hline
\end{tabular}


Table 2: Mean Performance Measures for Nine Baseball Stars

\begin{tabular}{|c|c|c|c|c|c|c|c|}
\hline & $\begin{array}{l}\text { Home- } \\
\text { runs }\end{array}$ & $\begin{array}{l}\text { Batting } \\
\text { Average }\end{array}$ & $\begin{array}{l}\text { Slugging } \\
\text { Pct. }\end{array}$ & RBI & $\begin{array}{l}\text { Strike- } \\
\text { outs }\end{array}$ & $\begin{array}{c}\text { Intent- } \\
\text { ional } \\
\text { Walks }\end{array}$ & $\begin{array}{c}\text { Base on } \\
\text { Balls }\end{array}$ \\
\hline $\begin{array}{l}\text { Jose } \\
\text { Canseco }\end{array}$ & 28.25 & 0.268 & 0.515 & 85.06 & 117.50 & 3.81 & 55.62 \\
\hline $\begin{array}{l}\text { Rafael } \\
\text { Palmeiro }\end{array}$ & 29.33 & 0.289 & 0.518 & 93.72 & 69.11 & 8.44 & 68.00 \\
\hline $\begin{array}{l}\text { Jason } \\
\text { Giambi }\end{array}$ & 29.89 & 0.299 & 0.539 & 100.44 & 94.89 & 6.89 & 91.56 \\
\hline $\begin{array}{l}\text { Mark } \\
\text { McGwire }\end{array}$ & 36.44 & 0.262 & 0.584 & 88.38 & 99.75 & 9.38 & 82.31 \\
\hline $\begin{array}{l}\text { Juan } \\
\text { Gonzalez }\end{array}$ & 28.60 & 0.286 & 0.537 & 92.47 & 83.60 & 4.87 & 29.87 \\
\hline $\begin{array}{l}\text { Ivan } \\
\text { Rodriguez }\end{array}$ & 17.77 & 0.302 & 0.486 & 70.31 & 65.77 & 3.69 & 27.62 \\
\hline $\begin{array}{l}\text { Ken } \\
\text { Caminiti }\end{array}$ & 36.44 & 0.262 & 0.584 & 88.38 & 99.75 & 9.38 & 82.31 \\
\hline $\begin{array}{l}\text { Dave } \\
\text { Martinez }\end{array}$ & 5.36 & 0.264 & 0.370 & 36.00 & 57.43 & 3.07 & 36.50 \\
\hline $\begin{array}{l}\text { Ken } \\
\text { Griffey Jr. }\end{array}$ & 32.06 & 0.289 & 0.552 & 92.27 & 83.73 & 13.60 & 62.67 \\
\hline $\begin{array}{l}\text { Ryne } \\
\text { Sandberg }\end{array}$ & 18.80 & 0.283 & 0.448 & 70.73 & 83.93 & 3.93 & 50.73 \\
\hline $\begin{array}{l}\text { Cecil } \\
\text { Fielder }\end{array}$ & 24.54 & 0.251 & 0.472 & 77.54 & 101.23 & 5.85 & 53.31 \\
\hline $\begin{array}{l}\text { All Power } \\
\text { Hitters }\end{array}$ & 9.55 & 0.258 & 0.397 & 41.78 & 51.76 & 3.31 & 32.40 \\
\hline
\end{tabular}


Table 3: The Effect of Canseco on Hitting Statistics for Power Position Players

\begin{tabular}{|c|c|c|c|c|c|c|c|}
\hline & Homeruns & Strikeouts & RBI & $\begin{array}{l}\text { Slugging } \\
\text { Percentage }\end{array}$ & $\begin{array}{l}\text { Batting } \\
\text { Average }\end{array}$ & $\begin{array}{l}\text { Intentional } \\
\text { Walks }\end{array}$ & $\begin{array}{c}\text { Base on } \\
\text { Balls }\end{array}$ \\
\hline $\begin{array}{l}\text { Playing with } \\
\text { Canseco }\end{array}$ & $\begin{array}{c}1.126 \\
(0.657)\end{array}$ & $\begin{array}{c}0.786 \\
(2.305)\end{array}$ & $\begin{array}{c}3.383 \\
(2.170)\end{array}$ & $\begin{array}{c}0.007 \\
(0.007)\end{array}$ & $\begin{array}{c}0.005 \\
(0.003)\end{array}$ & $\begin{array}{c}0.253 \\
(0.336)\end{array}$ & $\begin{array}{c}2.740 \\
(1.670)\end{array}$ \\
\hline $\begin{array}{l}\text { After Playing } \\
\text { with Canseco }\end{array}$ & $\begin{array}{c}2.909 \\
(0.643)\end{array}$ & $\begin{array}{c}8.307 \\
(2.255)\end{array}$ & $\begin{array}{c}9.174 \\
(2.124)\end{array}$ & $\begin{array}{c}0.012 \\
(0.006)\end{array}$ & $\begin{array}{c}0.005 \\
(0.003)\end{array}$ & $\begin{array}{c}0.938 \\
(0.329)\end{array}$ & $\begin{array}{c}6.869 \\
(1.634)\end{array}$ \\
\hline $\begin{array}{l}\text { Annual Division } \\
\text { Batting Average }\end{array}$ & $\begin{array}{l}141.961 \\
(14.397)\end{array}$ & $\begin{array}{l}278.055 \\
(50.504)\end{array}$ & $\begin{array}{l}420.748 \\
(47.552)\end{array}$ & $\begin{array}{c}1.501 \\
(0.145)\end{array}$ & $\begin{array}{c}0.499 \\
(0.074)\end{array}$ & $\begin{array}{l}10.829 \\
(7.367)\end{array}$ & $\begin{array}{l}259.629 \\
(36.589)\end{array}$ \\
\hline $\begin{array}{l}\text { Manager's } \\
\text { Lifetime Winning } \\
\text { Pct. }\end{array}$ & $\begin{array}{c}6.677 \\
(2.021)\end{array}$ & $\begin{array}{l}-13.088 \\
(7.091)\end{array}$ & $\begin{array}{l}18.034 \\
(6.676)\end{array}$ & $\begin{array}{c}0.108 \\
(0.020)\end{array}$ & $\begin{array}{c}0.035 \\
(0.010)\end{array}$ & $\begin{array}{c}0.683 \\
(1.034)\end{array}$ & $\begin{array}{c}-3.206 \\
(5.137)\end{array}$ \\
\hline $\begin{array}{l}\text { Ballpark } \\
\text { Hitting Factor }\end{array}$ & $\begin{array}{c}0.101 \\
(0.018)\end{array}$ & $\begin{array}{c}0.078 \\
(0.064)\end{array}$ & $\begin{array}{c}0.230 \\
(0.060)\end{array}$ & $\begin{array}{c}0.001 \\
(0.000)\end{array}$ & $\begin{array}{c}0.000 \\
(0.000)\end{array}$ & $\begin{array}{l}-0.004 \\
(0.009)\end{array}$ & $\begin{array}{c}0.100 \\
(0.046)\end{array}$ \\
\hline $\begin{array}{l}\text { Division } \\
\text { Dummies }\end{array}$ & Yes & Yes & Yes & Yes & Yes & Yes & Yes \\
\hline $\begin{array}{l}\text { Experience } \\
\text { Dummies }\end{array}$ & Yes & Yes & Yes & Yes & Yes & Yes & Yes \\
\hline Year Dummies & Yes & Yes & Yes & Yes & Yes & Yes & Yes \\
\hline $\begin{array}{l}\text { Individual } \\
\text { Fixed-Effects }\end{array}$ & Yes & Yes & Yes & Yes & Yes & Yes & Yes \\
\hline
\end{tabular}

Standard errors are in parentheses. Each column represents a separate regression, with the dependent variable indicated at the top of the table. The sample is composed of "power position" players which include players in the following positions: catcher, first base, designated hitter, and the outfield. The sample includes data from the 1970 to 2003 seasons. Jose Canseco has been deleted from the sample. Tenure and year dummies are included for every three year interval. 
Table 4: The Effect of Canseco on other Performance Statistics for Power Players

\begin{tabular}{|c|c|c|c|c|c|c|}
\hline & Steals & $\begin{array}{l}\text { Fielding } \\
\text { Percentage }\end{array}$ & Errors & At-Bats & $\begin{array}{l}\text { Games } \\
\text { Played }\end{array}$ & $\begin{array}{l}\text { Home- } \\
\text { Runs }\end{array}$ \\
\hline $\begin{array}{l}\text { Playing with } \\
\text { Canseco }\end{array}$ & $\begin{array}{c}0.774 \\
(0.714)\end{array}$ & $\begin{array}{l}-0.002 \\
(0.002)\end{array}$ & $\begin{array}{c}0.524 \\
(0.311)\end{array}$ & $\begin{array}{c}16.392 \\
(12.726)\end{array}$ & $\begin{array}{c}3.323 \\
(3.346)\end{array}$ & $\begin{array}{c}0.558 \\
(0.487)\end{array}$ \\
\hline $\begin{array}{l}\text { After } \\
\text { Playing with } \\
\text { Canseco }\end{array}$ & $\begin{array}{c}0.745 \\
(0.698)\end{array}$ & $\begin{array}{c}0.003 \\
(0.002)\end{array}$ & $\begin{array}{c}0.238 \\
(0.304)\end{array}$ & $\begin{array}{c}53.338 \\
(12.453)\end{array}$ & $\begin{array}{l}12.081 \\
(3.078)\end{array}$ & $\begin{array}{l}1.060 \\
(0.477)\end{array}$ \\
\hline $\begin{array}{l}\text { Annual } \\
\text { Division } \\
\text { Batting } \\
\text { Average }\end{array}$ & $\begin{array}{c}4.610 \\
(15.637)\end{array}$ & $\begin{array}{c}0.029 \\
(0.044)\end{array}$ & $\begin{array}{l}25.956 \\
(6.817)\end{array}$ & $\begin{array}{l}1531.290 \\
(278.843)\end{array}$ & $\begin{array}{l}397.226 \\
(68.933)\end{array}$ & $\begin{array}{c}88.865 \\
(10.689)\end{array}$ \\
\hline $\begin{array}{l}\text { Manager's } \\
\text { Lifetime } \\
\text { Winning } \\
\text { Pct. }\end{array}$ & $\begin{array}{l}1.278 \\
(2.195)\end{array}$ & $\begin{array}{c}0.007 \\
(0.006)\end{array}$ & $\begin{array}{l}-3.250 \\
(0.957)\end{array}$ & $\begin{array}{l}-97.946 \\
(39.149)\end{array}$ & $\begin{array}{l}-9.820 \\
(9.678)\end{array}$ & $\begin{array}{l}10.073 \\
(1.498)\end{array}$ \\
\hline $\begin{array}{l}\text { Ballpark } \\
\text { Hitting } \\
\text { Factor }\end{array}$ & $\begin{array}{c}0.024 \\
(0.020)\end{array}$ & $\begin{array}{l}-0.000 \\
(0.000)\end{array}$ & $\begin{array}{c}0.005 \\
(0.009)\end{array}$ & $\begin{array}{c}0.476 \\
(0.354)\end{array}$ & $\begin{array}{c}0.140 \\
(0.088)\end{array}$ & $\begin{array}{c}0.085 \\
(0.014)\end{array}$ \\
\hline At-bats & & & & & & $\begin{array}{c}0.0347 \\
(0.0004)\end{array}$ \\
\hline $\begin{array}{l}\text { Division } \\
\text { Dummies }\end{array}$ & Yes & Yes & Yes & Yes & Yes & Yes \\
\hline $\begin{array}{l}\text { Tenure } \\
\text { Dummies }\end{array}$ & Yes & Yes & Yes & Yes & Yes & Yes \\
\hline $\begin{array}{l}\text { Year } \\
\text { Dummies }\end{array}$ & Yes & Yes & Yes & Yes & Yes & Yes \\
\hline $\begin{array}{l}\text { Individual } \\
\text { Fixed- } \\
\text { Effects }\end{array}$ & Yes & Yes & Yes & Yes & Yes & Yes \\
\hline
\end{tabular}

Observations $=9062$

Players $=1499$

Standard errors are in parentheses. Each column represents a separate regression, with the dependent variable indicated at the top of the table. The sample is composed of "power position" players which include players in the following positions: catcher, first base, designated hitter, and the outfield. The sample includes data from the 1970 to 2003 seasons. Jose Canseco has been deleted from the sample. Tenure and year dummies are included for every three year interval. 
Table 5: The Effect of Canseco on the Performance Statistics for other Players

Performance Measures for Skilled Positions

Performance

of Pitchers

\begin{tabular}{lccccccc} 
& Homeruns & $\begin{array}{c}\text { Batting } \\
\text { Average }\end{array}$ & $\begin{array}{c}\text { Slugging } \\
\text { Percentage }\end{array}$ & $\begin{array}{c}\text { Fielding } \\
\text { Percentage }\end{array}$ & Steals & & ERA \\
\cline { 2 - 5 } \cline { 5 - 6 } & & & & & \\
$\begin{array}{l}\text { Playing with } \\
\text { Canseco }\end{array}$ & -1.333 & 0.008 & 0.001 & 0.001 & 1.236 & & -0.069 \\
& $(0.707)$ & $(0.005)$ & $(0.008)$ & $(0.002)$ & $(0.957)$ & & $(0.111)$ \\
$\begin{array}{l}\text { After Playing } \\
\text { with Canseco }\end{array}$ & 0.270 & 0.014 & 0.015 & -0.002 & -0.042 & & -0.145 \\
& $(0.672)$ & $(0.004)$ & $(0.008)$ & $(0.002)$ & $(0.909)$ & & $(0.105)$ \\
\hline
\end{tabular}

ERA

After Playing

With:

\begin{tabular}{|c|c|c|c|c|c|c|}
\hline Palmeiro & $\begin{array}{c}0.788 \\
(0.755)\end{array}$ & $\begin{array}{c}0.012 \\
(0.005)\end{array}$ & $\begin{array}{c}0.023 \\
(0.009)\end{array}$ & $\begin{array}{c}0.001 \\
(0.002)\end{array}$ & $\begin{array}{c}0.501 \\
(1.022)\end{array}$ & $\begin{array}{l}-0.068 \\
(0.125)\end{array}$ \\
\hline Giambi & $\begin{array}{c}1.432 \\
(1.271)\end{array}$ & $\begin{array}{c}-0.005 \\
(0.008)\end{array}$ & $\begin{array}{c}-0.006 \\
(0.015)\end{array}$ & $\begin{array}{c}0.000 \\
(0.004)\end{array}$ & $\begin{array}{c}1.728 \\
(1.721)\end{array}$ & $\begin{array}{c}0.017 \\
(0.190)\end{array}$ \\
\hline McGwire & $\begin{array}{c}0.471 \\
(0.863)\end{array}$ & $\begin{array}{c}-0.002 \\
(0.006)\end{array}$ & $\begin{array}{c}0.005 \\
(0.010)\end{array}$ & $\begin{array}{c}0.001 \\
(0.003)\end{array}$ & $\begin{array}{l}-1.843 \\
(1.167)\end{array}$ & $\begin{array}{l}-0.061 \\
(0.135)\end{array}$ \\
\hline Gonzalez & $\begin{array}{c}-0.366 \\
(0.891)\end{array}$ & $\begin{array}{c}0.001 \\
(0.006)\end{array}$ & $\begin{array}{c}0.001 \\
(0.010)\end{array}$ & $\begin{array}{c}0.000 \\
(0.003)\end{array}$ & $\begin{array}{c}-0.200 \\
(1.206)\end{array}$ & $\begin{array}{c}0.020 \\
(0.143)\end{array}$ \\
\hline Rodriguez & $\begin{array}{c}1.097 \\
(1.044)\end{array}$ & $\begin{array}{c}0.013 \\
(0.007)\end{array}$ & $\begin{array}{c}0.017 \\
(0.012)\end{array}$ & $\begin{array}{c}0.003 \\
(0.003)\end{array}$ & $\begin{array}{c}0.983 \\
(1.413)\end{array}$ & $\begin{array}{l}-0.241 \\
(0.171)\end{array}$ \\
\hline Martinez & $\begin{array}{c}0.433 \\
(0.693)\end{array}$ & $\begin{array}{c}-0.000 \\
(0.005)\end{array}$ & $\begin{array}{c}0.004 \\
(0.007)\end{array}$ & $\begin{array}{c}-0.001 \\
(0.002)\end{array}$ & $\begin{array}{c}-0.900 \\
(0.937)\end{array}$ & $\begin{array}{c}0.087 \\
(0.104)\end{array}$ \\
\hline Caminiti & $\begin{array}{c}-0.191 \\
(0.882)\end{array}$ & $\begin{array}{l}-0.007 \\
(0.006)\end{array}$ & $\begin{array}{c}0.011 \\
(0.010)\end{array}$ & $\begin{array}{c}0.004 \\
(0.003)\end{array}$ & $\begin{array}{l}-1.677 \\
(1.201)\end{array}$ & $\begin{array}{c}0.181 \\
(0.131)\end{array}$ \\
\hline Griffey Jr. & $\begin{array}{c}-0.049 \\
(0.991)\end{array}$ & $\begin{array}{c}0.003 \\
(0.007)\end{array}$ & $\begin{array}{c}0.007 \\
(0.011)\end{array}$ & $\begin{array}{c}0.009 \\
(0.003)\end{array}$ & $\begin{array}{c}-0.149 \\
(1.340)\end{array}$ & $\begin{array}{c}0.053 \\
(0.152)\end{array}$ \\
\hline Sandberg & $\begin{array}{l}-0.257 \\
(0.996)\end{array}$ & $\begin{array}{c}0.010 \\
(0.007)\end{array}$ & $\begin{array}{c}0.026 \\
(0.012)\end{array}$ & $\begin{array}{c}0.003 \\
(0.003)\end{array}$ & $\begin{array}{c}1.582 \\
(1.351)\end{array}$ & $\begin{array}{c}-0.006 \\
(0.123)\end{array}$ \\
\hline Fielder & $\begin{array}{c}1.103 \\
(0.933) \\
\end{array}$ & $\begin{array}{c}-0.003 \\
(0.006)\end{array}$ & $\begin{array}{c}0.005 \\
(0.011) \\
\end{array}$ & $\begin{array}{c}0.006 \\
(0.003) \\
\end{array}$ & $\begin{array}{c}1.879 \\
(1.261) \\
\end{array}$ & $\begin{array}{l}-0.151 \\
(0.124)\end{array}$ \\
\hline
\end{tabular}

Standard errors are in parentheses. Each column in the upper panel of the table represents a separate regression, with the dependent variable indicated at the top of the table. Skilled position players include the following positions: second base, third base, and shortstop. The sample is from the 1970 to 2003 seasons. The number of skilled position players is 4547 which includes panel data on 796 players. The sample of pitchers includes 10561 observations and 1862 players. Jose Canseco has been deleted from the sample. Tenure and year dummies are included for every three year interval. In the lower panel of the table, each coefficient came from a separate regression which is specified similarly to the ones in the top panel but use the indicated player instead of Jose Canseco as the independent variable. ERA stands for "earned run average." 
Table 6: The Effect of Canseco on Power Hitters after Dropping the Named Names

\begin{tabular}{|c|c|c|c|c|c|c|}
\hline runs & Strikeouts & RBI & $\begin{array}{c}\text { Slugging } \\
\text { Percentage }\end{array}$ & $\begin{array}{l}\text { Batting } \\
\text { Average }\end{array}$ & $\begin{array}{l}\text { Intentional } \\
\text { Walks }\end{array}$ & $\begin{array}{c}\text { Base on } \\
\text { Balls }\end{array}$ \\
\hline
\end{tabular}

Results from Full Sample of Power Hitters

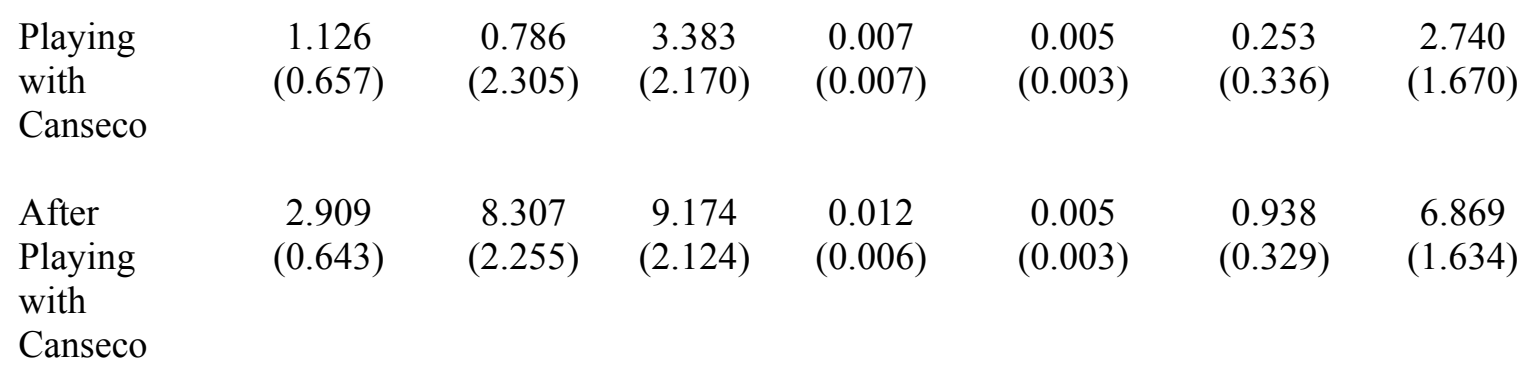

Results after Dropping the 6 Names Mentioned by Canseco

\begin{tabular}{|c|c|c|c|c|c|c|c|}
\hline $\begin{array}{l}\text { Playing } \\
\text { with } \\
\text { Canseco }\end{array}$ & $\begin{array}{c}0.911 \\
(0.668)\end{array}$ & $\begin{array}{c}0.720 \\
(2.373)\end{array}$ & $\begin{array}{c}2.319 \\
(2.228)\end{array}$ & $\begin{array}{c}0.006 \\
(0.007)\end{array}$ & $\begin{array}{c}0.004 \\
(0.003)\end{array}$ & $\begin{array}{c}0.137 \\
(0.344)\end{array}$ & $\begin{array}{c}2.533 \\
(1.714)\end{array}$ \\
\hline $\begin{array}{l}\text { After } \\
\text { Playing } \\
\text { with }\end{array}$ & $\begin{array}{c}1.471 \\
(0.667)\end{array}$ & $\begin{array}{c}6.782 \\
(2.366)\end{array}$ & $\begin{array}{c}5.293 \\
(2.221)\end{array}$ & $\begin{array}{c}0.003 \\
(0.007)\end{array}$ & $\begin{array}{c}0.002 \\
(0.003)\end{array}$ & $\begin{array}{c}0.524 \\
(0.344)\end{array}$ & $\begin{array}{c}4.734 \\
(1.709)\end{array}$ \\
\hline
\end{tabular}

Canseco

Standard errors are in parentheses. Power positions include catcher, first base, designated hitter, and the outfield. The sample includes data from the 1970 to 2003 seasons. Jose Canseco has been deleted from the sample. Tenure and year dummies are included for every three year interval. In the upper panel of the table, each column represents a different regression which is specified in Table 3 (the other coefficients have been suppressed). The lower panel includes similar regressions but after deleting the five named players from the sample. 
Table 7: The Effect of other Great Power Hitters on other Power Position Players

\begin{tabular}{|c|c|c|c|c|c|c|c|}
\hline \multirow[b]{2}{*}{$\begin{array}{l}\text { After Playing } \\
\text { with: }\end{array}$} & \multirow[t]{2}{*}{ Homeruns } & \multirow[t]{2}{*}{ Strikeouts } & \multirow[t]{2}{*}{ RBI } & \multirow[t]{2}{*}{$\begin{array}{c}\text { Slugging } \\
\text { Percentage }\end{array}$} & \multirow[t]{2}{*}{$\begin{array}{c}\text { Batting } \\
\text { Average }\end{array}$} & \multirow[t]{2}{*}{$\begin{array}{l}\text { Intentional } \\
\text { Walks }\end{array}$} & \multirow[t]{2}{*}{ At-Bats } \\
\hline & & & & & & & \\
\hline Canseco & $\begin{array}{c}2.909 \\
(0.643)\end{array}$ & $\begin{array}{c}8.307 \\
(2.255)\end{array}$ & $\begin{array}{l}9.174 \\
(2.124)\end{array}$ & $\begin{array}{c}0.012 \\
(0.006)\end{array}$ & $\begin{array}{c}0.005 \\
(0.003)\end{array}$ & $\begin{array}{c}0.938 \\
(0.329)\end{array}$ & $\begin{array}{c}53.338 \\
(12.453)\end{array}$ \\
\hline Palmeiro & $\begin{array}{l}-1.113 \\
(0.802)\end{array}$ & $\begin{array}{l}-6.081 \\
(2.823)\end{array}$ & $\begin{array}{l}-5.042 \\
(2.654)\end{array}$ & $\begin{array}{l}-0.006 \\
(0.008)\end{array}$ & $\begin{array}{l}-0.005 \\
(0.004)\end{array}$ & $\begin{array}{c}-0.592 \\
(0.411)\end{array}$ & $\begin{array}{l}-32.868 \\
(15.590)\end{array}$ \\
\hline Giambi & $\begin{array}{l}-0.671 \\
(1.162)\end{array}$ & $\begin{array}{c}5.853 \\
(4.076)\end{array}$ & $\begin{array}{l}-0.487 \\
(3.839)\end{array}$ & $\begin{array}{l}-0.000 \\
(0.012)\end{array}$ & $\begin{array}{l}-0.002 \\
(0.006)\end{array}$ & $\begin{array}{c}1.031 \\
(0.593)\end{array}$ & $\begin{array}{c}10.348 \\
(22.520)\end{array}$ \\
\hline McGwire & $\begin{array}{l}-0.254 \\
(0.828)\end{array}$ & $\begin{array}{c}2.809 \\
(2.917)\end{array}$ & $\begin{array}{l}-0.216 \\
(2.747)\end{array}$ & $\begin{array}{c}0.003 \\
(0.008)\end{array}$ & $\begin{array}{l}-0.001 \\
(0.004)\end{array}$ & $\begin{array}{c}0.389 \\
(0.424)\end{array}$ & $\begin{array}{c}20.153 \\
(16.130)\end{array}$ \\
\hline Gonzalez & $\begin{array}{l}-0.419 \\
(0.803)\end{array}$ & $\begin{array}{l}-2.640 \\
(2.823)\end{array}$ & $\begin{array}{l}-1.850 \\
(2.654)\end{array}$ & $\begin{array}{c}0.001 \\
(0.008)\end{array}$ & $\begin{array}{l}-0.001 \\
(0.004)\end{array}$ & $\begin{array}{l}-0.322 \\
(0.412)\end{array}$ & $\begin{array}{c}1.284 \\
(15.601)\end{array}$ \\
\hline Rodriguez & $\begin{array}{c}1.253 \\
(0.968)\end{array}$ & $\begin{array}{c}8.527 \\
(2.295)\end{array}$ & $\begin{array}{c}3.201 \\
(3.198)\end{array}$ & $\begin{array}{c}0.012 \\
(0.010)\end{array}$ & $\begin{array}{c}0.003 \\
(0.005)\end{array}$ & $\begin{array}{l}-0.026 \\
(0.495)\end{array}$ & $\begin{array}{c}32.430 \\
(18.751)\end{array}$ \\
\hline Martinez & $\begin{array}{l}-0.326 \\
(0.616)\end{array}$ & $\begin{array}{l}-5.089 \\
(2.158)\end{array}$ & $\begin{array}{l}-2.312 \\
(2.034)\end{array}$ & $\begin{array}{l}-0.003 \\
(0.006)\end{array}$ & $\begin{array}{c}0.001 \\
(0.003)\end{array}$ & $\begin{array}{c}0.071 \\
(0.315)\end{array}$ & $\begin{array}{l}-15.105 \\
(11.923)\end{array}$ \\
\hline Caminiti & $\begin{array}{l}-1.260 \\
(0.790)\end{array}$ & $\begin{array}{l}-2.168 \\
(2.770)\end{array}$ & $\begin{array}{l}-5.812 \\
(2.606)\end{array}$ & $\begin{array}{l}-0.012 \\
(0.008)\end{array}$ & $\begin{array}{l}-0.007 \\
(0.004)\end{array}$ & $\begin{array}{l}-1.029 \\
(0.403)\end{array}$ & $\begin{array}{l}-22.146 \\
(15.277)\end{array}$ \\
\hline Griffey Jr. & $\begin{array}{l}-3.393 \\
(0.868)\end{array}$ & $\begin{array}{l}-7.587 \\
(3.058)\end{array}$ & $\begin{array}{l}-7.680 \\
(2.874)\end{array}$ & $\begin{array}{l}-0.011 \\
(0.009)\end{array}$ & $\begin{array}{l}-0.001 \\
(0.004)\end{array}$ & $\begin{array}{l}-1.127 \\
(0.445)\end{array}$ & $\begin{array}{c}-45.564 \\
(16.889)\end{array}$ \\
\hline Sandberg & $\begin{array}{l}1.582 \\
(0.782)\end{array}$ & $\begin{array}{l}-2.185 \\
(2.741)\end{array}$ & $\begin{array}{c}2.064 \\
(2.582)\end{array}$ & $\begin{array}{l}-0.001 \\
(0.008)\end{array}$ & $\begin{array}{l}-0.004 \\
(0.004)\end{array}$ & $\begin{array}{c}0.110 \\
(0.400)\end{array}$ & $\begin{array}{c}-23.733 \\
(15.136)\end{array}$ \\
\hline Fielder & $\begin{array}{l}-1.079 \\
(0.746)\end{array}$ & $\begin{array}{l}-4.280 \\
(2.619)\end{array}$ & $\begin{array}{c}0.603 \\
(2.469)\end{array}$ & $\begin{array}{l}-0.004 \\
(0.008)\end{array}$ & $\begin{array}{c}0.000 \\
(0.004)\end{array}$ & $\begin{array}{c}-0.208 \\
(0.383)\end{array}$ & $\begin{array}{c}0.478 \\
(14.499)\end{array}$ \\
\hline
\end{tabular}

Standard errors are in parentheses. Each coefficient came from a separate regression which is specified similarly to the ones in Table 3 but use the indicated player instead of Jose Canseco as the independent variable. The displayed coefficient from each regression is for the variable "after playing with" the indicated player. 
Table 8: The Best Homerun Hitters of Canseco's Era

$\begin{array}{cccc}\text { Debut } & \text { Top 50 in } & \text { Top 51- } & \text { Years Led League in } \\ \text { Year } & \text { Career } & 100 \text { in } & \text { Homeruns (1985-2001) } \\ & \text { Homeruns } & \text { Career } & \\ & & & \\ & & & \end{array}$

$\begin{array}{lll}\text { Jose Canseco } & 1985 & \text { X } \\ \text { Rafael Palmeiro } & 1986 & \text { X } \\ \text { Mark McGwire } & 1986 & \text { X } \\ \text { Juan Gonzalez } & 1989 & \text { X } \\ \text { Ken Griffey Jr. } & 1989 & \text { X } \\ \text { Barry Bonds } & 1986 & \text { X } \\ \text { Sammy Sosa } & 1989 & \text { X } \\ \text { Fred McGriff } & 1986 & \text { X } \\ \text { Gary Sheffield } & 1988 & \text { X } \\ \text { Cal Ripken Jr } & 1981 & \text { X } \\ \text { Andres Galarraga } & 1985 & \text { X } \\ \text { Joe Carter } & 1983 & \text { X }\end{array}$

AL88,AL91

AL87,AL96,NL98,NL99

AL92,AL93

AL94,AL97,AL98,AL99

NL93,NL01

$\mathrm{NLO0}$

AL89,NL92

NL96

1985

1989

1989

1987

1981

1989

1987

1981

1983

1987

1981

1981

1984

1988

1982
AL90, AL91

NL97

AL95

NL94

NL88

NL90

AL86

NL89

NL95

NL91

Howard Johnson

The 27 players listed are the full sample of players that entered the league between 1981 and 1989

and are currently in the top 100 list of players for career homeruns or led one of the two leagues in homeruns for at least one year between 1985 and 2001. 
Table 9: The Effect of the Best Homerun Hitters of Canseco's Era

\begin{tabular}{|c|c|c|c|c|c|c|c|}
\hline & \multicolumn{5}{|c|}{ Power Hitters } & \multicolumn{2}{|c|}{ Position Players } \\
\hline & $\begin{array}{l}\text { Home- } \\
\text { runs }\end{array}$ & $\begin{array}{l}\text { Strike- } \\
\text { outs }\end{array}$ & $\begin{array}{l}\text { Intent- } \\
\text { ional } \\
\text { Walks }\end{array}$ & RBI & $\begin{array}{l}\text { Slugging } \\
\text { Percent }\end{array}$ & $\begin{array}{l}\text { Batting } \\
\text { Average }\end{array}$ & $\begin{array}{c}\text { Slugging } \\
\text { Percent }\end{array}$ \\
\hline Canseco & $\begin{array}{c}2.909^{* * *} \\
(0.64)\end{array}$ & $\begin{array}{c}8.307^{* * *} \\
(2.26)\end{array}$ & $\begin{array}{c}0.938^{* * *} \\
(0.33)\end{array}$ & $\begin{array}{c}9.174^{* * *} \\
(2.12)\end{array}$ & $\begin{array}{l}0.012^{*} \\
(0.007)\end{array}$ & $\begin{array}{c}0.014^{\star * *} \\
(0.004)\end{array}$ & $\begin{array}{l}0.015^{\star *} \\
(0.008)\end{array}$ \\
\hline Palmeiro & $\begin{array}{r}-1.114 \\
(0.80)\end{array}$ & $\begin{array}{c}-6.081^{* *} \\
(2.82)\end{array}$ & $\begin{array}{r}-0.592 \\
(0.41)\end{array}$ & $\begin{array}{c}-5.042^{*} \\
(2.65)\end{array}$ & $\begin{array}{l}-0.006 \\
(0.008)\end{array}$ & $\begin{array}{l}0.012^{* *} \\
(0.005)\end{array}$ & $\begin{array}{c}0.023^{* * *} \\
(0.009)\end{array}$ \\
\hline McGwire & $\begin{array}{l}-0.254 \\
(0.83)\end{array}$ & $\begin{array}{l}2.809 \\
(2.92)\end{array}$ & $\begin{array}{l}0.389 \\
(0.42)\end{array}$ & $\begin{array}{l}-0.216 \\
(2.75)\end{array}$ & $\begin{array}{c}0.003 \\
(0.008)\end{array}$ & $\begin{array}{l}-0.002 \\
(0.006)\end{array}$ & $\begin{array}{c}0.005 \\
(0.010)\end{array}$ \\
\hline Gonzalez & $\begin{array}{l}-0.419 \\
(0.80)\end{array}$ & $\begin{array}{l}-2.640 \\
(2.82)\end{array}$ & $\begin{array}{l}-0.322 \\
(0.41)\end{array}$ & $\begin{array}{l}-1.850 \\
(2.65)\end{array}$ & $\begin{array}{c}0.001 \\
(0.008)\end{array}$ & $\begin{array}{c}0.001 \\
(0.006)\end{array}$ & $\begin{array}{c}0.001 \\
(0.010)\end{array}$ \\
\hline Griffey Jr. & $\begin{array}{c}-3.393^{* * *} \\
(0.87)\end{array}$ & $\begin{array}{c}-7.587^{* *} \\
(3.06)\end{array}$ & $\begin{array}{c}-1.128^{* *} \\
(0.44)\end{array}$ & $\begin{array}{c}-7.680^{* * *} \\
(2.87)\end{array}$ & $\begin{array}{l}-0.011 \\
(0.009)\end{array}$ & $\begin{array}{c}0.003 \\
(0.007)\end{array}$ & $\begin{array}{c}0.007 \\
(0.011)\end{array}$ \\
\hline Bonds & $\begin{array}{c}-2.548^{* * *} \\
(0.75)\end{array}$ & $\begin{array}{c}-9.585^{* * *} \\
(2.63)\end{array}$ & $\begin{array}{l}-0.497 \\
(0.37)\end{array}$ & $\begin{array}{c}-7.225^{\star * *} \\
(2.47)\end{array}$ & $\begin{array}{l}-0.005 \\
(0.008)\end{array}$ & $\begin{array}{c}0.004 \\
(0.006)\end{array}$ & $\begin{array}{l}-0.007 \\
(0.010)\end{array}$ \\
\hline Sosa & $\begin{array}{c}-1.674^{* *} \\
(0.80)\end{array}$ & $\begin{array}{c}-8.077^{* * *} \\
(2.84)\end{array}$ & $\begin{array}{l}-0.674 \\
(0.41)\end{array}$ & $\begin{array}{c}-5.051^{*} \\
(2.67)\end{array}$ & $\begin{array}{l}-0.006 \\
(0.008)\end{array}$ & $\begin{array}{c}0.002 \\
(0.006)\end{array}$ & $\begin{array}{l}0.019^{*} \\
(0.010)\end{array}$ \\
\hline McGriff & $\begin{array}{l}-0.298 \\
(0.77)\end{array}$ & $\begin{array}{l}4.010 \\
(2.70)\end{array}$ & $\begin{array}{r}-0.186 \\
(0.39)\end{array}$ & $\begin{array}{l}2.586 \\
(2.54)\end{array}$ & $\begin{array}{l}-0.011 \\
(0.008)\end{array}$ & $\begin{array}{l}-0.011^{*} \\
(0.006)\end{array}$ & $\begin{array}{c}-0.014 \\
(0.010)\end{array}$ \\
\hline Sheffield & $\begin{array}{l}0.247 \\
(0.74)\end{array}$ & $\begin{array}{c}-0.0720 \\
(2.60)\end{array}$ & $\begin{array}{c}-0.0501 \\
(0.38)\end{array}$ & $\begin{array}{c}5.058^{* *} \\
(2.45)\end{array}$ & $\begin{array}{c}0.010 \\
(0.007)\end{array}$ & $\begin{array}{c}0.007 \\
(0.006)\end{array}$ & $\begin{array}{c}0.010 \\
(0.010)\end{array}$ \\
\hline Ripken Jr. & $\begin{array}{l}-0.789 \\
(0.81)\end{array}$ & $\begin{array}{c}-5.089^{*} \\
(2.85)\end{array}$ & $\begin{array}{l}-0.198 \\
(0.42)\end{array}$ & $\begin{array}{l}-3.873 \\
(2.68)\end{array}$ & $\begin{array}{l}-0.010 \\
(0.008)\end{array}$ & $\begin{array}{c}0.006 \\
(0.006)\end{array}$ & $\begin{array}{c}0.010 \\
(0.011)\end{array}$ \\
\hline Galarraga & $\begin{array}{c}0.0817 \\
(0.72)\end{array}$ & $\begin{array}{l}-3.445 \\
(2.52)\end{array}$ & $\begin{array}{c}-0.0827 \\
(0.37)\end{array}$ & $\begin{array}{l}0.934 \\
(2.37)\end{array}$ & $\begin{array}{c}0.005 \\
(0.007)\end{array}$ & $\begin{array}{c}0.000 \\
(0.005)\end{array}$ & $\begin{array}{l}-0.004 \\
(0.009)\end{array}$ \\
\hline Carter & $\begin{array}{l}0.802 \\
(0.66)\end{array}$ & $\begin{array}{l}1.952 \\
(2.33)\end{array}$ & $\begin{array}{l}0.355 \\
(0.34)\end{array}$ & $\begin{array}{c}5.030^{* * *} \\
(2.19)\end{array}$ & $\begin{array}{c}0.004 \\
(0.007)\end{array}$ & $\begin{array}{c}0.006 \\
(0.005)\end{array}$ & $\begin{array}{c}0.011 \\
(0.009)\end{array}$ \\
\hline Fielder & $\begin{array}{l}-1.079 \\
(0.75)\end{array}$ & $\begin{array}{l}-4.280 \\
(2.62)\end{array}$ & $\begin{array}{c}-0.208 \\
(0.38)\end{array}$ & $\begin{array}{l}0.603 \\
(2.47)\end{array}$ & $\begin{array}{l}-0.004 \\
(0.008)\end{array}$ & $\begin{array}{l}-0.003 \\
(0.006)\end{array}$ & $\begin{array}{c}0.005 \\
(0.011)\end{array}$ \\
\hline Walker & $\begin{array}{l}0.149 \\
(0.88)\end{array}$ & $\begin{array}{l}-1.166 \\
(3.10)\end{array}$ & $\begin{array}{c}-1.023^{* *} \\
(0.45)\end{array}$ & $\begin{array}{l}1.270 \\
(2.92)\end{array}$ & $\begin{array}{c}0.007 \\
(0.009)\end{array}$ & $\begin{array}{l}-0.004 \\
(0.007)\end{array}$ & $\begin{array}{l}-0.006 \\
(0.012)\end{array}$ \\
\hline Belle & $\begin{array}{c}-2.114^{* * *} \\
(0.74)\end{array}$ & $\begin{array}{c}-5.422^{* *} \\
(2.60)\end{array}$ & $\begin{array}{c}-0.774^{* *} \\
(0.38)\end{array}$ & $\begin{array}{c}-6.804^{* * *} \\
(2.45)\end{array}$ & $\begin{array}{c}-0.017^{* *} \\
(0.007)\end{array}$ & $\begin{array}{l}-0.006 \\
(0.006)\end{array}$ & $\begin{array}{l}-0.000 \\
(0.011)\end{array}$ \\
\hline Williams & $\begin{array}{l}0.368 \\
(0.69)\end{array}$ & $\begin{array}{l}-2.028 \\
(2.43)\end{array}$ & $\begin{array}{c}1.128^{* * *} \\
(0.35)\end{array}$ & $\begin{array}{l}-0.952 \\
(2.29)\end{array}$ & $\begin{array}{c}0.021^{* * *} \\
(0.007)\end{array}$ & $\begin{array}{c}0.003 \\
(0.007)\end{array}$ & $\begin{array}{c}0.013 \\
(0.012)\end{array}$ \\
\hline Gaetti & $\begin{array}{c}-1.412^{* *} \\
(0.66)\end{array}$ & $\begin{array}{l}-3.655 \\
(2.30)\end{array}$ & $\begin{array}{c}0.0585 \\
(0.34)\end{array}$ & $\begin{array}{c}-7.004^{\star * *} \\
(2.17)\end{array}$ & $\begin{array}{l}-0.008 \\
(0.007)\end{array}$ & $\begin{array}{l}-0.006 \\
(0.005)\end{array}$ & $\begin{array}{l}-0.014 \\
(0.009)\end{array}$ \\
\hline Vaughn & $\begin{array}{l}-0.471 \\
(0.77)\end{array}$ & $\begin{array}{l}0.753 \\
(2.71)\end{array}$ & $\begin{array}{c}-0.992^{* *} \\
(0.40)\end{array}$ & $\begin{array}{l}-1.865 \\
(2.55)\end{array}$ & $\begin{array}{l}-0.001 \\
(0.008)\end{array}$ & $\begin{array}{l}-0.001 \\
(0.006)\end{array}$ & $\begin{array}{c}0.003 \\
(0.010)\end{array}$ \\
\hline Burks & $\begin{array}{l}0.462 \\
(0.71)\end{array}$ & $\begin{array}{l}0.351 \\
(2.50)\end{array}$ & $\begin{array}{c}0.0860 \\
(0.37)\end{array}$ & $\begin{array}{l}0.838 \\
(2.36)\end{array}$ & $\begin{array}{l}0.012^{*} \\
(0.007)\end{array}$ & $\begin{array}{c}0.001 \\
(0.005)\end{array}$ & $\begin{array}{l}-0.005 \\
(0.009)\end{array}$ \\
\hline Davis & $\begin{array}{l}1.043^{*} \\
(0.63)\end{array}$ & $\begin{array}{c}5.254^{* *} \\
(2.20)\end{array}$ & $\begin{array}{l}0.428 \\
(0.32)\end{array}$ & $\begin{array}{l}3.881^{*} \\
(2.07)\end{array}$ & $\begin{array}{l}0.015^{* *} \\
(0.006)\end{array}$ & $\begin{array}{c}0.000 \\
(0.005)\end{array}$ & $\begin{array}{l}-0.000 \\
(0.009)\end{array}$ \\
\hline Strawberry & $\begin{array}{l}-0.475 \\
(0.70)\end{array}$ & $\begin{array}{l}-1.388 \\
(2.46)\end{array}$ & $\begin{array}{l}0.106 \\
(0.36)\end{array}$ & $\begin{array}{l}-0.853 \\
(2.32)\end{array}$ & $\begin{array}{l}-0.001 \\
(0.007)\end{array}$ & $\begin{array}{l}-0.005 \\
(0.005)\end{array}$ & $\begin{array}{c}-0.017^{* *} \\
(0.008)\end{array}$ \\
\hline Gant & $\begin{array}{c}-1.327^{*} \\
(0.80)\end{array}$ & $\begin{array}{l}-1.383 \\
(2.80)\end{array}$ & $\begin{array}{l}0.269 \\
(0.41)\end{array}$ & $\begin{array}{l}-3.852 \\
(2.64)\end{array}$ & $\begin{array}{l}-0.006 \\
(0.008)\end{array}$ & $\begin{array}{c}-0.011^{* *} \\
(0.005)\end{array}$ & $\begin{array}{l}-0.015^{*} \\
(0.008)\end{array}$ \\
\hline Sandberg & $\begin{array}{c}1.582^{* *} \\
(0.78)\end{array}$ & $\begin{array}{l}-2.185 \\
(2.74)\end{array}$ & $\begin{array}{l}0.110 \\
(0.40)\end{array}$ & $\begin{array}{l}2.064 \\
(2.58)\end{array}$ & $\begin{array}{l}-0.001 \\
(0.008)\end{array}$ & $\begin{array}{c}0.011 \\
(0.007)\end{array}$ & $\begin{array}{l}0.026^{* *} \\
(0.012)\end{array}$ \\
\hline Barfield & $\begin{array}{r}-0.600 \\
(1.01)\end{array}$ & $\begin{array}{l}-0.606 \\
(3.52)\end{array}$ & $\begin{array}{l}0.363 \\
(0.51)\end{array}$ & $\begin{array}{c}-0.0696 \\
(3.32)\end{array}$ & $\begin{array}{l}-0.007 \\
(0.010)\end{array}$ & $\begin{array}{c}0.007 \\
(0.008)\end{array}$ & $\begin{array}{l}-0.007 \\
(0.013)\end{array}$ \\
\hline Mitchell & $\begin{array}{l}-0.472 \\
(0.63)\end{array}$ & $\begin{array}{l}-2.442 \\
(2.20)\end{array}$ & $\begin{array}{l}-0.371 \\
(0.32)\end{array}$ & $\begin{array}{l}-3.080 \\
(2.07)\end{array}$ & $\begin{array}{l}-0.002 \\
(0.006)\end{array}$ & $\begin{array}{l}-0.001 \\
(0.005)\end{array}$ & $\begin{array}{c}0.009 \\
(0.009)\end{array}$ \\
\hline Bichette & $\begin{array}{l}0.437 \\
(0.73)\end{array}$ & $\begin{array}{l}2.207 \\
(2.55)\end{array}$ & $\begin{array}{l}0.433 \\
(0.37)\end{array}$ & $\begin{array}{l}1.033 \\
(2.40)\end{array}$ & $\begin{array}{c}0.022^{* * *} \\
(0.007)\end{array}$ & $\begin{array}{l}-0.005 \\
(0.005)\end{array}$ & $\begin{array}{l}-0.013 \\
(0.009)\end{array}$ \\
\hline Johnson & $1.562^{* \star}$ & -0.432 & -0.255 & 2.943 & 0.008 & -0.001 & -0.001 \\
\hline & $(0.66)$ & $(2.30)$ & $(0.34)$ & $(2.17)$ & $(0.007)$ & $(0.005)$ & $(0.009)$ \\
\hline
\end{tabular}

Standard errors are in parentheses. * indicates significance at the $10 \%$ level, ** indicates significance at the 5\% level, and $* * *$ indicates significance at the $1 \%$ level. Each coefficient came from a separate regression which is specified similarly to the ones in Table 3 but use the indicated player instead of Jose Canseco as the independent variable. The displayed coefficient from each regression is for the variable "after playing with" the indicated player. The 27 players listed are the ones described in Table 8. 